\title{
Keystone Links of Anthropogenic Environmental Problems and Emergence of Interconnected Man- made Environmental Crises
}

Sivakumaran Sivaramanan ( $\nabla$ sivaramanansr@gmail.com )

IIC University of Technology https://orcid.org/0000-0002-9904-2977

Sarath Wimalabandara Kotagama

University of Colombo

\section{Research Article}

Keywords: environment, environmental problems, manmade environmental problems, keystone environmental problems, interconnected environmental problems

Posted Date: November 30th, 2021

DOI: https://doi.org/10.21203/rs.3.rs-444535/v1

License: (c) (i) This work is licensed under a Creative Commons Attribution 4.0 International License. Read Full License 


\section{Abstract}

Background: Environmental problems are on a hike. The study provides evidenceof the links between manmade environmental issues based on cause-and-effect relationship from real-world examples. For instance, man-made climate change is caused primarily by deforestation, draining of wetlands, intensive farming, and air pollution (greenhouse gas emission). Also, each of these problems, air pollution for instance, is caused by intensive farming, burning of fossil fuels (because of the global energy crisis), urbanization, and methane emission from solid waste dumps. Deforestation is mainly caused by increasedhuman population, poverty, overexploitation of natural resources, urbanization, mining minerals, intensive farming, the establishment of dams, wildfires during El Niño, acid rain, and global warming (cyclic as cause and effect). Besides, every man-made environmental problem may cause various other environmental problems, such as air pollution causes ocean acidification, ozone depletion, acid rain, disease, and visual pollution (smog). Similarly, deforestation causes biodiversity loss, land degradation, and human-animal conflict.

Results: About 252 links were examined among 40 identified environmental issues. In this web, certain causative environmental problems were established as "keystone links". Possible keystone environmental problems were identified from the concept map based on the criteria given by the following approach, when mitigating a man-made environmental problem, if it results in the permanent disappearance of one or more man-made environmental problems, then that mitigated problem can be considered as a possible keystone environmental problem in a hypothetical situation where human adaptability factors such as economic, social, and political factors are absent.

Conclusions: Eight man-made environmental problems were found as keystones such as air pollution, deforestation, population explosion, overexploitation of natural resources, global energy crisis, intensive farming, water pollution-water scarcity, and urbanization-urban sprawl-settlements.

\section{Background}

The Gaia hypothesis first proposed by James Lovelock in 1969 stated "all living things on earth function as one super organism that changes its environment to create conditions that best meet its needs". Also, hypothesis further justifies that all living things (super organism) poses the ability to self-regulate the system by successfully adapting to the changes or by overcoming the changes by its natural resilience. This cooperative not competitive process ascertains the continuity of life on this planet through evolution. However, in this Anthropocene era man-made environmental problems severely affect this natural self-regulating and co-operative phenomenon. Man-made environmental problems are the human caused changes in the environment that alters the surrounding and makes it unfavorable for existence of life.

According to "Environmental Challenges," 1997(1), in the early days environmental issues gained public attention due to either their impacts on communities or prediction of such problems by scientists and others on likely effects of certain issues before these problems capture the wide recognition. According to "Environmental Challenges," 1997 (1), early environmental issues such as fish kill in contaminated surface waters, smog hazes over many American cities, the effects of DDT and other pesticides on wildlife, effects of

acid rain on ecosystems, effects of lead on infants and children, effects of tributyl tin on marine environment 
were considered as environmental problems and increased public concern on these issues caused US EPA to pass few laws in order to protect the environment and people, such as clean air act, clean water act and safe drinking water act. As a result, problems such as lead poisoning, air and water pollution were successfully mitigated in the period between 1978 and 1995. In addition, international treaties such as Montreal protocol (1987) which led to take measures to protect stratospheric ozone layer by banning CFC and related products globally and enabled us to recover from the impacts of UV radiation. It is further stated in the "Environmental Challenges," 1997(1), that environmental systems are complex and interconnected.

"Environmental challenges," 1997(1) further stated that present humans are experiencing the environmental problems that have neverbeen experienced before in this century and they are manmade, it is also mentioned that attempting to correct one environmental problem unknowingly create or exacerbate other environmental problems. For instance, after EPA has reduced the emission of particles larger than $2 \mathrm{~mm}$ by $78 \%$ (2) as cited in (1), the air became clearer but it caused another problem of acid deposition in the region of north-eastern United States. This is because the larger particles in the emission were alkaline and it neutralizes the acidity caused by smaller sulphur oxide particles. And in the absence of alkaline large particles, smaller acid sulphur oxide accumulated in the air and lead to acid deposition. Mitigation to $\mathrm{SO}_{\mathrm{x}}$ also reduced the concentration of acid aerosol. This created another unexpected problem that the sulphuric acid aerosol also served as nuclei for the formation of clouds. More the nuclei smaller the droplets in the atmosphere. Usually, these droplets scatter incoming solar radiation before reaching the earth's surface resulting in dimming or global cooling effect, but in the absence of aerosol in the air the impact of global warming (3) intensified as cited in (1). In addition, aerosol particles are normally found in combustion emission along with manmade $\mathrm{CO}_{2}$, however, unlike $\mathrm{CO}_{2}$, aerosol particles have harmful effects on the human health. Due to this global mitigation of aerosol emission by China (in particular) reduced the aerosol pollution by 2006, and as it peaked in the same year, it caused severe respiratory health issues, and the global warming was accelerated (4).

Similarly, in early 1950s, Dayak people suffered from malaria. WHO had permitted to spray huge amount of DDT to kill mosquitoes. The attempt was a success and vector borne disease malaria was mitigated, however, their houses began to fall down on their heads. This is because application of DDT also killed the parasitic wasp that had previously controlled thatch eating caterpillars. In this scenario the worst event is DDT poisoned insects were eaten by geckos, which were eaten by cats, the cats died and the rat population increased. The people were affected by sylvatic plague and typhus. To find solution to this WHO was obliged to parachute 14,000 live cats into Borneo (5).

Thus, unless we understand the problems and their behavior including the links based on cause-and-effect relationships it is not possible to overcome the problems permanently. According to (6) as cited in (7), in order to achieve this, we need to travel beyond "sustaining innovation" and "disruptive innovation" and should effectively engage in "transformative innovation". Wahl (7) stated that transformative innovation requires integrative whole system thinking and we can innovate win-win-win solutions and design for this systemic synergy. Wahl (7) further stated, "to do so, we need to understand the interconnected nature of the converging crisis and respond with an integrative and participatory approach to this complexity". In this way solutions can be created for the benefit of entire biosphere and ecosystem (7). 


\section{Literature Review}

Environmental systems are complex and interconnected (1). Present humans are experiencing the environmental problems that have not been experienced before in this century and they are manmade (1). In 1986 United States Environmental Protection Agency (USEPA) embarked on analyzing the risk caused by more than 30 environmental issues $(8,9)$ and subsequently United States National Research Council (USNRC) addressed these on the same basis as risk characterization $(10,11,9)$.

A "casual model" derived from (12) gives key characteristics of environmental problems such as persistence of the pollutant in the environment, the population exposed and health impacts. Vicky and co-authors (9) have also defined a sum of 18 specific descriptors to measure these characters.

In the UNEP (2012) report 21 issues were categorized based on the following criteria:

i. Issues that are critical to the global environment. Issues can be either positive or negative. But must be environmental in nature or environmentally related.

ii. Issues that were recognized as 'emerging' based on newness, which can be the result of new scientific knowledge, new scales or accelerated rates of impacts, increased level of awareness and/or new ways to respond to the issues.

iii. Issues have a large spatial scale, and they should be global, continental, or 'universal' in nature (issues that occur in many parts of the world).

iv. Given priority over the next 1-3 years in the work programme of UNEP and/or other UN institutions and/or other international institutions concerned with the global environment.

Table 1. Environmental problems studied for interconnections 


\begin{tabular}{|c|c|c|c|c|c|c|c|}
\hline $\begin{array}{l}\text { Overexploitation } \\
\text { of Natural } \\
\text { Resources }\end{array}$ & E1 & $\begin{array}{l}\text { Ocean } \\
\text { Acidification }\end{array}$ & E13 & Air pollution & E25 & $\begin{array}{l}\text { Human \& } \\
\text { Animal } \\
\text { Conflict }\end{array}$ & E37 \\
\hline $\begin{array}{l}\text { Vector-borne } \\
\text { diseases }\end{array}$ & E2 & Eutrophication & E14 & $\begin{array}{l}\text { Animal Slaughter } \\
\text { \& Cruelty }\end{array}$ & E26 & $\begin{array}{l}\text { Poverty- } \\
\text { Disease- } \\
\text { Disability- } \\
\text { Inequality-War- } \\
\text { Food } \\
\text { insecurity }\end{array}$ & E38 \\
\hline $\begin{array}{l}\text { Global Energy } \\
\text { Crisis }\end{array}$ & E3 & $\begin{array}{l}\text { Groundwater } \\
\text { contamination- } \\
\text { depletion- } \\
\text { salinization }\end{array}$ & E15 & $\begin{array}{l}\text { Climate change } \\
\text { and Global } \\
\text { warming }\end{array}$ & E27 & $\begin{array}{l}\text { Nuclear } \\
\text { explosions- } \\
\text { radiation- } \\
\text { nuclear } \\
\text { wastes }\end{array}$ & E39 \\
\hline $\begin{array}{l}\text { El-Nino \& La } \\
\text { Nino }\end{array}$ & N4 & Oil spills & E16 & $\begin{array}{l}\text { Deforestation- } \\
\text { loss of } \\
\text { grasslands- sea } \\
\text { grass beds\& } \\
\text { mangroves }\end{array}$ & E28 & Agrochemicals & E40 \\
\hline $\begin{array}{l}\text { Biodiversity } \\
\text { Loss }\end{array}$ & E5 & Plastic pollution & E17 & $\begin{array}{l}\text { Coral destruction } \\
\text { \& bleach }\end{array}$ & E29 & $\begin{array}{l}\text { Population } \\
\text { Explosion }\end{array}$ & E41 \\
\hline $\begin{array}{l}\text { Wetlands or } \\
\text { draining of } \\
\text { wetlands }\end{array}$ & E6 & $\begin{array}{l}\text { Thermal } \\
\text { Pollution }\end{array}$ & E18 & Ozone depletion & E30 & $\begin{array}{l}\text { Invasive } \\
\text { species or } \\
\text { Exotic species }\end{array}$ & E42 \\
\hline $\begin{array}{l}\text { Land } \\
\text { degradation- } \\
\text { sedimentation- } \\
\text { soil erosion }\end{array}$ & E7 & Solid waste & E19 & Acid Rain & E31 & $\begin{array}{l}\text { Intensive } \\
\text { farming }\end{array}$ & E43 \\
\hline $\begin{array}{l}\text { Pollution } \\
\text { through mining } \\
\text { activities }\end{array}$ & E8 & $\begin{array}{l}\text { Heavy metal } \\
\text { contamination }\end{array}$ & E20 & Light Pollution & E32 & Aquatic Weeds & E44 \\
\hline $\begin{array}{l}\text { Establishment } \\
\text { of Dams }\end{array}$ & E9 & Pests or weeds & E21 & $\begin{array}{l}\text { Noise \& Vibration } \\
\text { pollution }\end{array}$ & E34 & & \\
\hline $\begin{array}{l}\text { Urbanization- } \\
\text { urban sprawl- } \\
\text { settlements }\end{array}$ & E10 & $\begin{array}{l}\text { Hazardous } \\
\text { waste }\end{array}$ & E23 & $\begin{array}{l}\text { Impacts of } \\
\text { biotechnology \& } \\
\text { Nanotechnology }\end{array}$ & E35 & & \\
\hline $\begin{array}{l}\text { Water Pollution } \\
\& \text { Water Scarcity }\end{array}$ & E12 & E-Waste & E24 & Visual Pollution & E36 & $\begin{array}{l}\text { E11, E22 \&E33 } \\
\text { are not } \\
\text { available }\end{array}$ & \\
\hline
\end{tabular}

[N.B. - Numbers given to the man-made environmental problems (E \#\#) in the table 1 (below) are given in brackets in the following part of the literature and discussion.]

Man-made environmental problems are interconnected as cause and effect to one another.UNEP report gave 21 emerging environmental issues for the 21 st century which were ranked based on their linkages to the various dimensions of sustainable development. These issues cut across major global environmental 
themes such as food production, food insecurity (E38), urbanization (E10), biodiversity (E05), freshwater (E12), marine (E13, E16, E17, and E18), climate change (E27), energy (E03), technology and waste (E19). In addition, report also concentrated on bridging the technology among countries, giving adequate funds or support to developing countries in order to combat the global environmental change and inclusive green economy. On 25th of September 2015 at United Nation's sustainable development summit, 2030 agenda for sustainable development was developed with the participation of world leaders from over 150 nations. The seventeen Sustainable Development Goals (SDG) are aiming to end poverty (E38), end hunger (E38), ascertain good health (E38) and wellbeing, quality education, gender equality, clean water (E12) and sanitation, affordable and clean energy (E03), decent work and economic growth (E38), develop industry, innovation and infrastructure, reduce inequalities, establishing sustainable cities (E10) and communities (E41), ensure responsible consumption and production (E01), climate change (E27) and disaster risk, protecting aquatic life (E05, E16,E17, E29, E06,\&E18), protecting the life on land or secure the biodiversity (E05), democratic governance and peace building and establishing global partnerships to achieve these goals (13). Similarly, in the recent 2012 GEO 5 report, issues such as heavy metal toxicity (E20), invasive or alien species (E42), and water scarcity (E12) such as groundwater depletion (E15) were classified along with other modern issues. Two dozen of reports were reviewed by (14), included reports of National Research Council, EPA's Science Advisory Board, technical societies and research institutions.

In addition, according to the paper published by the Ministry of the Environment of Japan (2001), interconnected nature of several environmental problems such as overexploitation of natural resources, intensive farming, deforestation, energy crisis, urban sprawl, pollution (air/ fresh water, groundwater and marine), hazardous wastes, ozone depletion, soil degradation and acid rain were depicted (see figure 1).

Source: (15)

\section{Methods}

Qualitative content analysis methodology was used. Major environmental problems were screened from published documents. And precisely 252 links were found. To validate the hypothesis, existence of all 252 links should be affirmed with the support of real-world examples collected from the reliable scientific literature. A concept diagram was created with the principles of the visualization tools of the Stockholm Environment Institute (SEI) of the United Nations Environment Management Group (EMG), which depicts a complete "mental map" of relationships among the man-made environmental problems. Data collection was done until the data saturation was achieved or when major categories showed depth and variation. As archival work books, peer-reviewed journals, and papers from various sources including the internet were searched for relevant codes (links). The following diagram describes the functional flow of the qualitative content analysis methodology, see figure 2.Finally, keystone environmental problems were identified from the concept map based on the criteria given by the following approach. When mitigating a man-made environmental problem, if it results in the permanent disappearance of one or more man-made environmental problems, then that mitigated problem can be considered as a possible keystone man-made environmental problem, in a hypothetical situation where human adaptability factors such as economic, social, political, health, genetics, evolution and behavioural factors are absent (16). 
Source: (17)

\section{Results}

Man-made environmental problems are interconnected as cause and effect to one another. For instance, water pollution and water scarcity (E12) is caused by several other man-made environmental problems such as agrochemicals (E40), solid waste (E19), plastic pollution (E21), e-waste (E24), heavy metal contamination (E20), pollution through mining activities (E08), establishment of dams (E09), sedimentation and soil erosion (E07), over exploitation of natural resources (E01), hazardous waste (E23), intensive farming (E43), global warming and climate change (E27), groundwater contamination (E15), urbanization, urban sprawl and settlements(E10) and wetlands or draining of wetlands (E06). And the effects of water pollution (E12) are eutrophication (E14), biodiversity loss (E05) and disease and food insecurity (E38). Thus, man-made environmental problems are interconnected to one another as causes and effects. The following concept map depicts the interconnected nature of 40 man-made environmental problems based on causes and effects relationship. After a prolonged study (from 2013 Dec. - 2019 Jan.) on real world evidences from inter connections between selected man-made environmental problems the following concept map was developed(18) See figure3.

Similarly, causes of land degradation, desertification and soil erosion (E07) are deforestation and destruction of mangroves (E28), agrochemicals (E40), pollution through mining activities (E08), overexploitation of natural resources (E01) (excess land usage), intensive farming (E43), heavy metal contamination (E20), water pollution and water scarcity (E12), establishment of dams (E09), invasive species or exotic species (E42) (e.g. Eucalyptus sp. causes land degradation through its oily litter). Similarly, impacts of land degradation, desertification and soil erosion (E07)are poverty, disease, disability and food insecurity (E38), in this group of problems, land degradation (E07) causes impacts such as food insecurity (E38) (while the disease and disability caused by famine or malnutrition are less pronounced) and biodiversity loss (E05) (poor soil no longer harbor organism and biodiversity). In the aforesaid scenario twelve environmental issues are directly linked to the land degradation, desertification and soil erosion (E07) (ten causes and two impacts).

At present, based on above evaluated history on the environmental challenges stated by international authors, treaties, summits and conferences including the research gaps specified by (1) which is based on the interconnected nature of the man-made environmental issues, the main hypothesis of this study has been derived, that "Man-made environmental problems are interconnected and complex".

\section{Discussion}

\subsection{Identifying keystone environmental problems or keystone links}

When solving a man-made environmental problem, if it results in the permanent disappearance of one or more man-made environmental problems, then that mitigated problem can be considered as a possible 
keystone environmental problem.

Based on our definition of keystone environmental problem to be eligible for a possible keystone environmental problem, mitigation of a man-made environmental problem could solve one or more resultedman-made environmental problems. Accordingly, air pollution can be considered as a possible keystone problem, because if air pollution gets solved, the resulting acid rain and ozone depletion can also come to a halt.

The following literature-based evidence are not sufficient to make a firm decision on the term keystone environmental issue because the raw data for statistical calculation is not available. And conclusions cannot be derived from the general comparison of percentile values found in the literature. Thus, the term keystone man-made environmental problems remain a hypothetical term or can be called as possible keystone manmade environmental problem.

\subsubsection{Air pollution as a possible keystone environmental problem}

Air pollution is not new for this planet because 65 million years ago, during the Cretaceous period, the earth had experienced huge air pollution due to the clouds and smoke formed after the crash of a meteorite. This event caused mass extinction led to the complete elimination of dinosaurs and various other species.

Currently, pollution due to natural sources such as forest fires and volcano eruption is creating several tonnes of greenhouse gases and other pollutants, which are unable to find a human solution as they occur naturally. However, Global emission of $\mathrm{CO}_{2}$ reached 34.5 billion tonnes in 2012, and the yearly increase was $1.4 \%$ from that of 2011(19). Extreme weather patterns and environmental conditions observed as anthropogenic air pollutants are continuously released to the atmosphere and are increasing in quantity and intensity with time. In addition to global warming, acid rain and ozone depletion are well recognized for its severity. Man-made sources can be categorized by source as either point or non-point sources or by its formation as primary or secondary pollutants. Most primary pollutants are the emission of point sources such as factories and nonpoint sources such as motor vehicle traffic on high ways, whereas secondary pollutants originate by the chemical reaction of primary pollutants and generally non-point source of origin. In addition to naturally existing gases and particles, manmade compounds such as fumes and gases of plastic, heavy metals, pesticides, fibers, and chemical gases are extremely hazardous and cause severe health impacts. Air pollution is a global issue, it is a growing challenge since the time of industrialization and according to the World Bank report in 2013, China lost nearly $10 \%$ of its GDP, India 7.69\%, Sri Lanka and Cambodia roughly $8 \%$, among developed countries the UK lost $\$ 7.6 \mathrm{bn}$, the $\$ 45 \mathrm{bn}$ and Germany $\$ 18 \mathrm{bn}$ annually through lost workdays and welfare cost from premature death. According to WHO Global Ambient Air Quality Database, both in urban and rural areas an estimated 3.7 million premature deaths were caused all over the world in 2012. Yet 3 billion people still depend on coal and biomass fuel (indoor), which emit annually several billion tonnes of $\mathrm{CO}_{2}$, and other greenhouse gases to the atmosphere. Industries, power plants, and transport are some major anthropogenic sources. In the post-industrial era, air pollution can be considered as a possible keystone man-made environmental problem because termination of CFC air pollution and Sulphur dioxide air pollution would result in a complete solution to the ozone depletion and acid rain, respectively. See figure 4. 


\section{Evidence 1: Air pollution causes acid rain}

During the 1970s and 80 s acid rain was a huge environmental issue, and its impacts such as dead lakes, corroded statues, and increasing rate of asthma were the headlines of that time. According to Nixon \& Curran (20), in 1985, 21 countries including Canada signed the Helsinki Protocol. Accordingly, Canada was targeting to reduce $\mathrm{SO}_{2}$ emissions by $30 \%$ from the 1980 levels. In 1993, the Canadian acid rain control program was introduced, and this was targeted to reduce the $\mathrm{SO}_{2}$ emission by $50 \%$ from the 1980 level of 4.6 million tonnes. In 1990, the Clean Air Act amendments were introduced in the United States. And in 2000, title IV of the amendment promised to cut the $\mathrm{SO}_{2}$ emissions by 9.1 million tonnes. Furthermore, in 1991, Canada and the United States signed a bilateral agreement on air quality. This addressed acid rain and its causative transboundary air pollution issues. Nixon \& Curran(20) stated that the area of North America receiving loadings of wet sulphate over $20 \mathrm{~kg} / \mathrm{ha} / \mathrm{yr}$. depicted a significant reduction between 1980-82 and 1985-87. However, nitrate loading did not show any significant change during the same period.

According to Owens (21), Gene Likens, an ecologist at the University of Connecticut who first discovered the impacts of acid rain in 1963 at Hubbard Brook Experimental Forest in New Hampshire said that acidity in Hubbard Brook is now $80 \%$ less than it was in the 1960 s. "It has been a big success story," said Gene Likens.

Levels of $\mathrm{SO}_{2}$ in the USA in the 1970s were 31,218 thousand tons, and the level of $\mathrm{SO}_{2}$ in the USA in 2017 was 2,815 thousand tons (22). Thus, the reduction of $\mathrm{SO}_{2}$ in the atmosphere in the period between 1970 and 1917 is 28,403 thousand tons, and the percentage of reduction is $91 \%$. Thus, when it is assumed that the difference between 1960 and $1970 \mathrm{SO}_{2}$ levels are small and negligible, it is possible to say a $91 \%$ reduction in $\mathrm{SO}_{2}$ air pollution caused an $80 \%$ reduction in the acidity (acid rain) in Hubbard Brook. This is a general conclusion, the raw data of each value for the reduction in the acidity was not available for statistical calculations.

\section{Evidence 2: Air pollution causes ozone depletion}

After the Montreal protocol (1987) on substances that deplete the ozone layer, the Chlorofluorocarbon (CFC) ban was implemented, and the CFC refrigerators were replaced by ozone friendly product. As a result, the ozone layer is recovering. And the ozone hole is expected to heal completely by $2040-2070$. Thus, solving CFC air pollution extenuate the resulted ozone depletion issue.

[In the figure black circle is the problem being examined, blue circles are cause man-made environmental problems, red circles are effect man-made environmental problems, double lined circles are possible keystone man-made environmental problems, and circles with dashed lines (either single or double lined) are the manmade environmental problems that disappear when the problem being examined (black circle) is mitigated]

\subsubsection{Deforestation as a possible keystone environmental problem}

The rising human population and needs cause an increase in the exploitation of natural resources, mainly the forest. Changing patterns of consumption and techno machinery further fuel this issue. The world's annual 
deforestation is estimated at 13.7 million hectares, equal to the area of Greece. If this continues at the same rate, the total forest cover may completely vanish in the next hundred years. However, still, 30 percent of the land cover is occupied by forests. According to the DCCEE (Department of Climate Change and Energy Efficiency), the 2012 report estimated the current average net $\mathrm{CO}_{2}$ emission as $27 \mathrm{Mt}-\mathrm{e}$, and it is projected to be $43 \mathrm{Mt}-\mathrm{e}$ in 2020. We are inevitably committed to involving in the reconstruction of socio, economic and environmental factors to promote an inclusive developmental strategy to ensure the sustainability of forest ecosystem as it leads to the firm existence of life on our planet. Man started clearing forests several thousand years ago, mainly for agriculture and ranching purposes. In the nineteenth century transformation of Modern man in terms of industrialism, urbanism, liberal democracy, and capitalism resulted in him overexploiting nature, mainly nature's forest resource, this caused various negative impacts on the entire ecosystem, the change in weather patterns, global warming, the outbreak of epidemics, droughts, desertification, existence and distributional changes in the entire biota and its diversity. There is evidence of clearance of rain forest at least 3000 years ago in Africa, 7000 years ago in the south and Central America, and possibly 9000 years ago in India and New Guinea. Also, evidence of the slash and burn technique been practiced in Northern South America, South East Asia, and Central Africa 12,000 years ago. Land hunger, increased economic needs for resources caused the destruction. Historically, English, and Dutch migrants lured by a gold rush, collecting spices and monoculture plantations such as tea and rubber are the pioneer reasons for the destruction of forest cover in Brazilian Amazon, North America, and South Asian regions. When considering tropical rainforests, in Bangladesh, Haiti, India, and Sri Lanka almost all rainforests were lost by 1988, China lost 50\% in Xishuangbanna province. In the period between 1960 and 1985 Philippines and Thailand loss 55 and 45 percent of their rain forest respectively (23). In the year between 1990 and 2000 the world is estimated to have suffered a net loss of 8.9 million hectares of forest each year. But, in the period 2000-2005 this declined to an estimated 12.9 million hectares per year. The recent deforestation rate is annually 7.3 million ha. (24). Overall, the world lost about 3 percent of its forests during the period 1990 to 2005 , while at present we are losing about 200 square kilometers of forest each day. Deforestation can be considered as a possible keystone environmental problem, because solving deforestation may mitigate various other related issues such as air pollution, human and animal conflict, biodiversity loss, and desertification or land degradation (see figure 5).

\section{Evidence1: Deforestation causes air pollution}

According to Miteva, Loucks, \&Pattanayak (25), "between the period of 2000 and 2008 Forest Stewardship Council (FSC) has reduced the aggregate of deforestation by $5 \%$ points, and the incidence of air pollution by $31 \%$ points. It had no statistically significant impact on fire incidence or core areas, but increased forest perforation by $4 \mathrm{~km}^{2}$ on average".

\section{Evidence2: Deforestation causes biodiversity loss}

According to Grosberg, Vermeij, \& Wainwright (26), $80 \%$ of the species in the world are found in the terrestrial environment. Thus, deforestation causes habitat loss and subsequently leads to loss of biodiversity. Also, most of the human-animal conflict occurs due to the destruction of forest habitats.

\section{Evidence 3: Deforestation causes desertification or land degradation}


Worldwide 35 million $\mathrm{km}^{2}$ or $24 \%$ of the land area is degraded. And globally, $28 \%$ of the land is forest, and deforestation causes $47 \%$ of land degradation (27).

[In the figure black circle is the problem being examined, blue circles are cause man-made environmental problems, red circles are effect man-made environmental problems, double lined circles are possible keystone man-made environmental problems, and circles with dashed lines (either single or double lined) are the manmade environmental problems that disappear when the problem being examined (black circle) is mitigated]

\subsubsection{Overexploitation of natural resources as a possible keystone environmental problem}

According to "Overconsumption? Our Use of the World's Natural Resources" (28), today humans extract and use about $50 \%$ more natural resources than 30 years ago, around 60 billion tons of raw materials extracted each year, and this is further expected to increase to 100 billion tonnes by 2030 . This massive extraction causes environmental problems as well as human right violations due to poor working conditions. The world economy today uses around $30 \%$ fewer resources to produce one Euro or Dollar of GDP than 30 years ago, and overall consumption is still rising. People in rich countries consume up to 10 times more natural resources than the people of poor developing countries. Most resource-intensive areas are housing, food, and transport, while the utilisation rhythm varies vastly between developing countries and developed nations. An average British family that may comprise two children, would consume resources as high as the resource utilised by 10 children of a developing country. Furthermore, resulted pollution and other environmental issues are more complicated than that of in developing countries. E.g., effects of particle matter in the airthe Great Smog of London 1952.

Overfishing causes a severe problem in fish population and their genetic diversity. According to WWF, around $53 \%$ of the world's fish population is completely depleted, $32 \%$ are overexploited, depleted or recovering from depletion (29) Global fishing rate is more than 2-3 times larger than what oceans can sustainably support.

The many destructive practices and operations that contribute to this situation are: -

- increased catching of juvenile fish,

- pirate fishers who do not obey fishing laws,

- degradation of breeding grounds or spawning or nurseries by destructive fishing techniques,

- non-selective fishing methods such as bottom trawling destroys coral reef, reed beds, and shallow seagrass beds,

- cyanide fishing killing coral reef fishery in Mainland China, Hong Kong, Philippines, and Singapore,

- use of explosives such as dynamite fishing affects South East Asian coral reef fishery,

- Ghost fishing, where ghost nets are released in to the sea and it moves while catching dolphins, turtles and fishes unselectively. Sometimes about $1000 \mathrm{~km}$ of Ghost nets are released in the Pacific Ocean. According to "Destructive fishing practices" (30), trawlers with modern fish finders which also eliminate juvenile forms, consequently deplete the future stocks and entire population. 
Such similar overexploitation of natural resources are possible keystone links because it causes biodiversity loss (to a great extent), deforestation, land degradation, coral destruction, wetland loss or draining of wetlands, animal slaughter and cruelty, groundwater contamination, water pollution-water scarcity and pollution through mining activities. Furthermore, the problem varies based on the type of resource being exploited. When the resource depletion comes to an end, then problems such as biodiversity loss (almost) may get eliminated. Similarly, deforestation, land degradation, coral destruction, wetlands or draining of wetlands, animal slaughtering and cruelty, groundwater contamination, water pollution and scarcity, pollution through mining activities, all may disappear (See figure 6).

\section{Evidence 1: Overexploitation of natural resources causes biodiversity loss}

According to Waldman (31), "Human overexploitation of wildlife resources has caused $60 \%$ of biodiversity loss, a new report revealed in the last 40 years $60 \%$ of wildlife population has declined due to human pressure."

[In the figure black circle is the problem being examined, blue circles are cause man-made environmental problems, red circles are effect man-made environmental problems, double lined circles are possible keystone man-made environmental problems, and circles with dashed lines (either single or double lined) are the manmade environmental problems that disappear when the problem being examined (black circle) is mitigated]

\subsubsection{Global energy crisis as a possible keystone environmental problem}

Increasing industries around the world demand energy, this is primarily generated by consumption of nonrenewable energy resources such as fossil fuels, coal, oil, and gas. Over $80 \%$ of current energy needs depend on fossil fuels. Further, electricity generation, transports, and various industries still depend on fossil fuels as the sole source of energy. Energy demand is expected to rise by almost half of the present demand over the next two decades but energy resources have started to run out. The potential for an energy crisis when sources of non-renewable energy get deplete is very true, however, in the past two decades available gas resources have increased by $70 \%$, and oil reserves by $40 \%$, and it has been estimated that we have enough for thirty years supply(32). Besides, new oil and gas fields are being discovered all the time. Advanced recovery technologies open up several unconventional sources such as tar sands, shale gas, and ultra-deepwater are been considered. Furthermore, nuclear energy and increasing usage of technologies of renewable energy sources would pacify future emerging energy needs. However, at present the usage of renewable energy is too small compared to non-renewable sources. The major cause of the energy crisis is the increasing population and their needs for a quality lifestyle which also leads to overconsumption of oil, gas, and coal. However, it is associated with several other factors as given below: -

- Poor infrastructure: The aging of the infrastructure of power generators is another cause, old and nonupgraded fuel engine consume more fuel than modern or upgraded generators or engines.

- Unexplored renewable energy options: renewable energy remains unused in many countries, unlike fossil fuels, renewable energy does not result in greenhouse gases, thus worldwide movement towards clean energy is now a major concern. 
- Delay in commissioning of power plants: In many developing countries there is a delay in commissioning new power plants that can fill the gap between demand and supply of energy.

- Wastage of energy: energy is wasted in many ways such as failure to switching off the electric equipment when there is no need, use of vehicles to travel short distances, not using energy-efficient lights, and fail to use the maximum from daylight (using lights in sunny days) and energy leakages.

- Poor distribution system: This causes frequent tripping and break downs.

- Accidents and natural calamities: accidents such as oil spills and oil burns due to tanker accidents, explosions in refineries or storage, bursting of the pipeline to mention a few. Natural calamities such as volcanoes, floods, and earthquakes cause destruction and severe loss of fuel too e.g., Fukushima Daiichi nuclear disaster following the earthquake on 11th March 2011, caused several thousand to evacuate from the area, resulted in an economic loss ranging between $\$ 250-500$ billion and negative attitude towards further development of nuclear power generation.

- Wars and terror attacks: Wars between countries could hamper the global energy supply if it happens in Middle East countries, e.g., Gulf war in 1990 caused a severe rise in oil prices due to oil shortages

- Miscellaneous factors: tax hikes, strikes, military coup, political events, extreme climatic events may cause an increased demand for energy or affect the fuel or energy supply.

Source: (33)

- Pandemic - oil prices have even gone negative, uncertainty is very high, and thus production cutting happens.

Global energy crisis and burning of fossil fuels cause overexploitation of coal and other fossil fuel resources. Further, pollution through mining activities (including fracking); deforestation through intensive farming of oil palm, also cause air pollution (carbon sinks and particle filtration activity are lost through deforestation), the establishment of dams for hydropower generation, etc. Solving the global energy crisis may eliminate several of the above-mentioned problems such as pollution through mining activities (for crude oil \& gas), air pollution, and up to certain extent deforestation and intensive oil palm cultivation. It will also solve indirect links such as groundwater contamination by pollution through mining activities - fracking, and biodiversity loss because of deforestation. (see figure 7).

\section{Evidence 1: Global energy crisis causes air pollution}

According to the International Energy Agency (IEA) WEO-2016 a. Special Report Energy and Air Pollution (34) as cited in (35), energy-related fossil fuel combustion in high and middle-income countries and biomass burning in low-income countries account for most of the global air pollution, generating $85 \%$ of airborne respirable particulate pollution and almost all sulphur dioxide and nitrogen oxide emissions to the atmosphere.

\section{Evidence 2: Global energy crisis causes global warming and climate change}

According to the "OECD report" (36), fossil fuel combustion accounted for $84 \%$ of global greenhouse gas emission in 2009. 
[In the figure black circle is the problem being examined, blue circles are cause man-made environmental problems, red circles are effect man-made environmental problems, double lined circles are possible keystone man-made environmental problems, and circles with dashed lines (either single or double lined) are the manmade environmental problems that disappear when the problem being examined (black circle) is mitigated]

\subsubsection{Intensive farming as a possible keystone environmental problem}

Intensive agriculture is one of the largest contributors to man-made climate change, accounts for around $12 \%$ of total emissions, and a quarter of greenhouse gas emission. Animal agriculture accounts for $37 \%$ of methane emission and $65 \%$ of nitrous oxide. Also, runoff from farms causes eutrophication. Poor living conditions in industrial farms cause animal diseases and animals are said to be subject to cruel handling. Agrochemicals such as pesticides, fungicides, herbicides, and chemical fertilisers lead to toxic effects on waterways and the atmosphere and affect non-targeted biotas such as insects, birds, and other animals. Agrochemicals also affect soil microflora and fauna, cause soil salinisation and desertification. A high concentration of nitrate in groundwater from chemical fertiliser causes methemoglobinemia (blue baby syndrome). Nitrate and phosphate effluents from excessive chemical fertilisers lead to eutrophication that resulted in algal blooms that clogs the fish gills, and increases the biological oxygen demand. Intensive palm oil agriculture causes deforestation in Indonesia and affects orangutan habitats. Intensive farming including slash and burn techniques causes severe biodiversity loss and a threat to indigenous people. According to the Department of agriculture, in the United States the number of factory farms increased by $230 \%$ from 1982 to 2002. Besides, in the period between 1990 and 2015, pesticide usage worldwide has increased by $73 \%$. Antibiotics and growth hormones used in animal farming also affect humans (37).

Intensive farming results into problems, such as overexploitation of natural resources, desertification, deforestation, biodiversity loss, animal slaughtering and cruelty, agrochemicals, solid waste and sewage, eutrophication, groundwater contamination, the establishment of dams, water pollution-water scarcity, wetlands or draining of wetland, and hazardous waste from toxic pesticide chemicals. If intensive farming comes to an end, then problems such as resource depletion, desertification, deforestation, animal slaughtering and cruelty, agrochemicals, eutrophication, groundwater contamination, wetlands, and biodiversity loss (to a certain extent) get eliminated. (see figure 8)

\section{Evidence 1: Intensive farming causes agrochemical pollution}

Intensive farming with the use of chemical fertilizers and pesticides may result in several environmental issues such as eutrophication, land degradation- sedimentation- soil erosion, loss of biodiversity, overexploitation of natural resources, heavy metal contamination, water pollution, groundwater contamination, hazardous waste, deforestation, air pollution, global warming, solid waste and sewage, dam construction, coral destruction, animal slaughter, and cruelty and food insecurity diseases and poverty. However, based on the concept diagram (see Fig. 5.6) if intensive farming techniques are abandoned and replaced by organic farming or permaculture techniques then agrochemical problems get cease completely. Thus, intensive farming is a possible keystone environmental issue. 
According to Feuerbacher, Luckmann, Boysen, Zikeli, \&Grethe (38), the study revealed that Bhutan's largescale conversion to $100 \%$ organic agriculture by desolating the agrochemical methods resulted in $24 \%$ lower yields than conventional yields. The study also found a considerable reduction in Bhutan's GDP, substantial welfare losses, particularly for non-agricultural households, and adverse effects on food security. The reduction in agricultural yield was largely compensated by imported foods from India. And this situation also weakened the country's cereal self-sufficiency. Even though soil $\mathrm{P}$ and $\mathrm{K}$ remained unchanged, soil nitrogen levels gone down by (-22.4\%). Because nitrogen release from animal manure was too slow. However, the study also suggested overcoming these pitfalls Bhutan should improve fertilization management, crop protection, and integration of livestock to obtain better yield as truly holistic, organic farming. Thus, Bhutan's present agriculture policy and its implementation revealed that the absence of intensive farming brought the use of agrochemicals to a halt. Thus, it is clear that intensive farming is a possible keystone man-made environmental problem (based on the definition). However, increasing food demand as the result of an increasing population may question Bhutan's $100 \%$ organic policy in the future and it may further increase food insecurity and poverty in the country. Thus, the population explosion acts as the precursor link of major man-made environmental problems.

\section{Evidence 2: Intensive farming causes water pollution and scarcity}

According to FAO (39) as cited in (40) "agriculture accounts for $70 \%$ of total freshwater withdrawals on average worldwide, thus, agriculture is the largest water user in the world." and "these amounts can reach as much as $95 \%$ in some developing countries"(41) as cited in (40). Besides, "agriculture is the major source of water pollution such as nutrient loading, pesticide, and other contamination" (40).

\section{Evidence 3: Intensive farming causes deforestation}

According to the report 'Agriculture is the direct driver for worldwide deforestation' (42), "agriculture is estimated to be the direct drive for deforestation. $80 \%$ of deforestation worldwide is due to agriculture or intensive farming".

[In the figure black circle is the problem being examined, blue circles are cause man-made environmental problems, red circles are effect man-made environmental problems, double lined circles are possible keystone man-made environmental problems, and circles with dashed lines (either single or double lined) are the manmade environmental problems that disappear when the problem being examined (black circle) is mitigated]

\subsubsection{Water pollution-water scarcity as a possible keystone environmental problem}

According to "www.worldwildlife.org" (43), about 1.1 billion people all over the world lack access to freshwater, and 2.7 billion people find water scarcity for at least one month of the year. Inadequate sanitation is a problem for 2.4 billion people in the world, where diseases such as cholera, typhoid, and diarrhoea affect. Furthermore, 2 million people, mostly children, die each year from diarrhoeal disease alone. It has been predicted by 2025 two-third of the world population will face water shortages (43). Also, agriculture accounts for $70 \%$ of the global freshwater access, but $60 \%$ of this water used in irrigation are wasted through leaky irrigation. 
In the wastewater, decomposing waste material could produce malodorous gases, sewage consumes dissolved oxygen in the water bodies for its decomposition and raises the Biological Oxygen Demand (BOD) which lead to the fish kills, wastewater rich in nutrients can accelerate the algal blooms and causing eutrophication, as wastewater contains pathogens, toxic chemicals, and heavy metals. The purpose of the development of water treatment plants was initially to satisfy the environmental and health standards. As cities become larger and as the development of industrial processing zones created a huge amount of wastewater every day it increased the amount of wastewater exceeding the natural self-purification capacity of streams, ponds, and rivers. See figure 9 .

\section{Types of Water Pollution}

Nutrient pollution, Eutrophication and Natural succession, Aquatic weeds, Infectious Agents, Toxic organic water pollutants, Toxic inorganic water pollutants, Heavy metal pollutants, Nitrates and Nitrites, Phosphates, Salts, Oils, Colourings / Dyes, Acids, Chlorine, Sulphates, Sediment, Thermal pollution

\section{Sources of pollution}

Municipal wastewater, industrial wastewater, agriculture runoff, and storm water

\section{Evidence 1: Water pollution causes disease and food insecurity}

According to the Cornell University study (44); (45) as cited in (46), "water-related diseases responsible for $80 \%$ of all infectious diseases worldwide, and $90 \%$ of all diseases in developing world." Thus, if water pollution is solved completely, we can get rid of $80 \%$ of infectious diseases. This is a statistically significant solution. Thus, water pollution can be considered as a possible keystone issue.

[In the figure black circle is the problem being examined, blue circles are cause man-made environmental problems, red circles are effect man-made environmental problems, double lined circles are possible keystone man-made environmental problems, and circles with dashed lines (either single or double lined) are the manmade environmental problems that disappear when the problem being examined (black circle) is mitigated]

\subsubsection{Urbanization-urban sprawl-settlements as a possible keystone environmental problem}

According to United Nations (47), today $55 \%$ of the world population lives in urban areas, and by $205068 \%$ of the world population is projected to live in urban areas. The human population has utilized lands for various developmental needs; intense urbanization converts rural and untouched wild habitat areas into more intense use areas such as towns and cities. However, every human occupational role such as agriculture, fisheries, hunting, gathering, poultry, dairy, food, and beverage industry, textiles, fibre, leather, steel, energy, product manufacturing, transportation, and waste management faces the environmental challenges which cannot be combated in the absence of biodiversity and ecosystem services. Anthropogenic urban sprawl results, nuclear proliferation, war, global warming, coral mining, poaching, ozone depletion, acid rain, overexploitation (e.g. overfishing), ocean acidification, heavy metal pollution, noise pollution, generation of toxic gases and chemicals, garbage generation, and improper dumping, sewage, oil spills, heavy metal pollution, spreading of 
carcinogenic pollutants, habitat destruction including deforestation, destruction of mangroves, invasive species, intense sand mining, and desertification all threaten surrounding environment and continuity of life on earth. Also, pandemic diseases such as COVID 19 affected urban cities, e.g., Wuhan, New York, Ahmedabad, and Gujarat.

Besides, urbanization-urban sprawl-settlements causes solid waste and sewage, air pollution, water pollution and scarcity, visual pollution, deforestation, light pollution, noise and vibration pollution, global energy crisis, draining of wetland and biodiversity loss. If it is possible to find a clear solution for urbanization and urban sprawl, then most of the environmental problems such as solid waste and sewage, air pollution, water pollution and scarcity, visual pollution (by man-made structures), light pollution, noise and vibration pollution, global energy crisis, draining of wetlands, deforestation (almost) and biodiversity loss (to a certain extent) could be eliminated. Indirect links such as climate change and global warming may be reduced. See Fig. 11.

\section{Evidence 1: Urbanisation-urban sprawl-settlements causes Global energy crisis}

According to UN-Habitat, urban cities consume $78 \%$ of the world's energy (48). If this relationship is statistically significant, in an imaginary situation where there is no urbanization or urban cities, then $78 \%$ of the causes of the energy crisis would have been solved.

\section{Evidence 2: Urbanisation-urban sprawl-settlements causes air pollution}

According to UN-Habitat, $60 \%$ of the global greenhouse emission is from urban cities (48).

\section{Evidence 3: Urbanisation-urban sprawl-settlements causes man-made global warming and climate change}

$60 \%$ of man-made global warming is due to urban cities, as $60 \%$ of greenhouse gas emission is from cities (48). However, in reality, removing possible keystone links is not possible due to the presence of human adaptability factors such as economic, social, political, health, genetics, evolution, and behavioural factors (16).

\section{Evidence 4: Urbanisation-urban sprawl-settlements causes light pollution}

According to "energy.gov" (49), at 4.00 PM on August 14, 2003, Midwest and Northeast United States and Canada experienced a cascading power cut which prolonged for four days. About 50 million people were affected by the event. However, they were able to see the clear night sky in the absence of light pollution. Even now the clean sky is observable in abandoned cities in California where urban city living is no more. According to "darksky.org" (50), $80 \%$ of the world's population lives under a sky glow. In the USA and Europe, $99 \%$ of the people cannot see the natural night sky. USA and Europe have converted regions of the world from cities to megacities with a huge urban network. Thus, if urbanization disappears, the light pollution also will disappear (see Fig. 10 and Fig. 11).

Source: (51)

[In the figure black circle is the problem being examined, blue circles are cause man-made environmental problems, red circles are effect man-made environmental problems, double lined circles are possible keystone 
man-made environmental problems, and circles with dashed lines (either single or double lined) are the manmade environmental problems that disappear when the problem being examined (black circle) is mitigated]

\subsubsection{Population explosion as a possible keystone environmental problem}

The increasing population causes deforestation, which leads to the loss of valuable genes, water regulators, flood controllers, watersheds, protectors of inland and coastal fisheries, and climate stabilisers. This also leads to the destruction of mineral cycles and several food chains, which are essential to keep the environment balanced.

As mentioned by Paul Ehrlich in Population Explosion, I=PAT, which means I: - impact in the environment equals population multiplied by $A$ : - affluence (the amount of energy and food supply the population consumes) multiplied by the amount of destructive $\mathrm{T}$ : - technology a country has, thus with the increasing population there are impacts on the environment.

More people need more space, more food from agriculture, fisheries, poultry and meat, more jobs, more vehicles, more energy, more water supply, more infrastructures such as apartments, shopping malls, factories, industries, more roads, railroads and highways, hospitals, schools, and playgrounds. This results in more pollution, more land degradation, more waste generation, more deforestation, more greenhouse gas emission and global warming, ozone depletion, more spreading of epidemics, more animal abuse and killing for meat, more acid rain and more chances for disasters such as radiation emission from nuclear power reactors, more chances for hazardous chemical discharge, oil spills, more excavation of soil and minerals cause more deadly landslides, increased terrorism and war.

In human history, the first revolution (cultural revolution) occurred 100,000 yrs. ago during the time of the Ice Age, when humans lived as a hunter-gatherer. They had more culturally expanded communities than earlier human forms. With the Food supply increases, there was a dramatic increase in population. By the end of the Ice Age, the human population was about 5 million. (52). The second revolution was around 8000 B.C., which is an agricultural revolution. Here humans were able to cultivate crops at the desired location, agriculture evolved. These agriculturists developed villages and towns; the population increased further. However, there were certain setbacks such as the Black Death (1346-1353) or the bubonic plague which killed around 75-200 million people in Europe. In the 1650s the world's population reached 500 million, and then in 1760, the industrial revolution (third revolution) began. This event deeply changed the human lifestyle, as fossil fuel replaced wood. Improvements in the fields such as medicine, economy, and sanitation followed. By the year 1800 , the hypothetical human population reached one billion. At the beginning of the 19th-century machines replaced human employees, this led to further improvement in the social status and standard of living in Europe and North America. In the year of 1900, the global population reached 1.6 billion and increased to 2 billion by 1927 (100\% increase). From 1943 with the green revolution (fourth revolution) it further skyrocketed and during the 20th century, it increased steeply to 6 billion (400\% increase in just 100 years). This exponential growth led to the high consumption of natural resources and man-made resources, which also brought about environmental problems such as deforestation, soil degradation and erosion, air water and land pollution, greenhouse gas emission, waste accumulation, and increased demand for freshwater. In

Page $18 / 42$ 
addition, it was estimated that 0.01 and $0.1 \%$ of all species become extinct each year (if $0.01 \%$ is true: 200 2000 and if $0.1 \%$ is true: $10,000-100,000$ species become extinct annually) (53). Furthermore, urban sprawl causes habitat destruction, invasive species, increased pollutants, and negative effects on human health such as spreading of pandemic (e.g., COVID 19 during 2020 in highly populated areas), obesity, stress, and hypertension.

The population explosion is the pioneer or precursor and a possible keystone link. We may find a solution to most of the environmental problems when the human population is reduced to that of the pre-industrial era. Today, the world's population is 7.7 billion, and it has been projected to rise to 10 billion by 2050 (54), or more accurately 9.1 billion by 2050 (55). The increasing population causes overexploitation of natural resources, deforestation, urbanization and urban sprawl, solid waste and sewage, the establishment of dams, intensive farming, global energy crisis and burning of fossil fuels, plastic waste, e-waste, and animal slaughter and cruelty. When the human population is reduced, then natural resources may be sustained, and problems such as deforestation, urban sprawl, solid waste, dams, intensive farming, energy crisis and fossil fuel burning, plastic waste, e-waste generation, animal slaughtering, and cruelty to animals may all come to an end. Along with indirectly linked problems such as biodiversity loss, caused by intensive farming and deforestation may also be reduced to a great extent. See figure 12 .

\section{Evidence 1: Population explosion causes intensive farming}

According to Harvey (54), the author raised the question "Can we ditch intensive farming - and still feed the world?" In brief, global food production must increase by $50 \%$ in the next 30 years, to serve the growing population that is about to reach 10 billion by 2050. Harvey, further elaborated that "compare to 2010 an extra 7,400tn calories is required in 2050." Also, by that time (2050), the world would require a landmass twice the size of India for food production to sustain the increased population. But the intensive farming and its related components such as inorganic fertilisers, chemical pesticides, GMO's, deforestation for agriculture are expected to be reduced or avoided by that time (2050), and to be substituted by organic farming, agroforestry, urban farming, and permaculture systems that are relatively less productive.

\section{Evidence 2: Population explosion causes urbanization-urban sprawl-settlements}

According to the United Nations (56)," $68 \%$ of the world population projected to live in urban areas by 2050. " It further elaborates that "today $55 \%$ of the world's population lives in urban areas, and the growing population tends to add another 2.5 billion people to urban areas by $2050 . "$

\section{Evidence 3: Population explosion causes water pollution \& scarcity}

According to "The Guardian" (57), the United Nations reported that "by 2050, 4.8 billion to 5.7 billion people will live in water-scarce areas at least for one month each year. And today, almost half of the world's population (3.6 billion) live in water-scarce areas. According to Malik, Yasar, Tabinda, \& Abubakar (58), "about $78 \%$ of the population was extracting groundwater at the rate of $2-3$ hours per a day, whereas, $4 \%$ and $2 \%$ population had the use of $4-5$ hours and 6 or more hours respectively per a day."

Evidence 4: Population explosion causes overexploitation of natural resources

Page 19/42 
According to "UNEP" (59),"International Resource Panel Report said material resource use expected to reach nearly 90 billion tonnes in 2017, and may more than double from 2015 to 2050." Thus, overexploitation of natural resources is expected to double by 2050 due to the increasing population and its growing needs.

\section{Evidence 5: Population explosion causes deforestation}

According to "Department of Economic and Social Affairs" (60),"the demand for wood alone is expected to triple to 10 billion cubic meters by 2050" However, "increasing population also increases the demand for agricultural production and conversion of forest to arable land to meet this demand in most of the tropical and low-income countries."

\section{Evidence 6: Population explosion causes global energy crisis or fossil fuel combustion}

According to "OECD report" (36), "global energy demand is rapidly increasing, arising from population and economic growth, thus, energy demand growth is projected to rise by $90 \%$ in 2035 . According to "Bloomberg" (61), "global electricity demand to increase $57 \%$ by $2050 . "$

Population explosion also tends to increase poverty, food security, solid waste and sewage, animal slaughter and cruelty, plastic pollution, e-waste, and draining of wetlands. Population explosion is a precursor to almost every environmental issue. If the human population remained unchanged since the pre-industrial era, the world would not face much of the present man-made environmental problems.

[In the figure black circle is the problem being examined, blue circles are cause man-made environmental problems, red circles are effect man-made environmental problems, double lined circles are possible keystone man-made environmental problems, and circles with dashed lines (either single or double lined) are the manmade environmental problems that disappear when the problem being examined (black circle) is mitigated]

It was also possible to identify the hypothetical path of the possible keystone environmental issues as given below (see figure13).

[In the figure black circle is the problem being examined, red circles are the effect man-made environmental problems, double lined circles are possible keystone man-made environmental problems, and circles with dashed lines are the man-made environmental problems that disappear when the problem being examined (black circle) is mitigated]

- According to the United Nations (56), today $55 \%$ of the world's population lives in urban areas.

- According to "UNEP" (59), overexploitation of natural resources expected to double by 2050 due to the increasing population and its growing needs.

- According to "OECD report" (36), "global energy demand is rapidly increasing, arising from population and economic growth, thus, energy demand growth is projected to rise by $90 \%$ in 2035 .

- According to Harvey(54), a question can be raised that "Can we ditch intensive farming - and still feed the world?" In brief, global food production must increase by $\mathbf{5 0 \%}$ in the next 30 years. 
- According to UN-Habitat, $60 \%$ of the global greenhouse emission is from urban cities (48)

- Agriculture is the direct driver for worldwide deforestation, $\mathbf{8 0 \%}$ of deforestation worldwide are due to agriculture or intensive farming (42).

- According to FAO (39) as cited in (40), agriculture accounts for $70 \%$ of total freshwater withdrawals on average worldwide.

- According to "OECD report" (36), fossil fuel combustion accounted for $\mathbf{8 4 \%}$ of global greenhouse gas emissions in 2009.

- According to International Energy Agency (IEA) WEO-2016b. Special Report Energy and Air Pollution (34) as cited in (35) "energy-related fossil fuel combustion in high and middle-income countries and biomass burning in low-income countries account for most of the global air pollution, generating $\mathbf{8 5 \%}$ of airborne respirable particulate pollution and almost all Sulphur dioxide and nitrogen oxide emissions to the atmosphere."

Above eight encircled man-made environmental issues are possible keystone links (hypothetically) and removing such links could bring many directly and indirectly linked environmental problems to an end. But human adaptability factors prevent such solutions in reality. Thus, instead of cutting links, shortcuts are established to solve the problem by regenerative means. However, this is not the case for all man-made environmental problems. Certain man-made environmental problems can be solved by either sustainable or regenerative or by both ways.

E.g., removing deforestation is not possible due to economic needs. And some government policies can influence severe deforestation (politics).

Thus, creative and intelligent way of finding an adaptable solution to the existing environment is required. And this can be achieved by regenerative solutions, for instance establishing floating wetland is a regenerative solution for eutrophication (see figure 14). Here, no source problem is mitigated as in sustainable solutions. But a bridge link is made by solving another environmental issue (draining of wetlands). Wetland plants absorb the excess nutrients from the intensive agricultural systems, and they can also adapt in density according to the changes in the nutrient flow.

The following concept diagram explains the scenario in a nutshell.

N.B.: - Each problem in the rectangles is connected to many other problems on the basis of cause and effect, and they are not shown here.

In addition, regenerative solutions require less energy compare to sustainable solutions (62). Thus, study provides a way to suggest sustainable to regenerative solutions to the environmental issues. In addition, discovery of keystone environmental problems (e.g. intensive farming in Fig. 2) further simplifies the solution of major environmental problem based on their cause - effect interconnections i.e. when intensive farming is mitigated all other resulted problems such as eutrophication, agrochemical contamination, groundwater contamination, water pollution and scarcity, dams, hazardous agrochemical wastes, deforestation, land degradation and soil erosion (salinization of soil), agricultural solid waste, wetlands (paddy fields), loss of 
biodiversity (due to mono culture \& habitat loss), global warming (methane from cattle farms) and animal cruelty may get disappeared or reduced.

On the whole, the project has several benefits, such as studying the interconnected nature of the crisis may facilitate the Environmental Impact Assessment (EIA) process and enable us to identify all possible linkages and resulted problems, problem analysis based on the links helps to find the hidden environmental issues and problem that could emerge when solving another, and concept map also supports the scientists to predict future environmental problems based on the links.

\section{Conclusions}

All man-made environmental problems are interconnected based on cause-and-effect relationships. Study was conducted using qualitative content analysis methodology. When mitigating a man-made environmental problem, if it results in the permanent disappearance of one or more man-made environmental problems, then that mitigated problem can be considered as a keystone environmental problem, in a hypothetical situation where human adaptability factors such as economic, social and political factors are absent. Following eight man-made environmental problems were identified as keystone environmental crises by the study, such as air pollution, deforestation, population explosion, overexploitation of natural resources, global energy crisis, intensive farming, water pollution-water scarcity, and urbanization-urban sprawl-settlements.

\section{Abbreviations}

US EPA

United States Environmental Protection Agency

WHO

World Health Organization

WWF

World Wildlife Fund

GDP

Gross Domestic Product

BOD

Biological Oxygen Demand

PM

Particle Matter

CFC

Chlorofluorocarbon

WEO

World Economic Outlook

IEA

International Energy Agency

OECD

Organization for Economic Co-operation and Development 
UNEP

the United Nations Environmental Programme

DCCEE

Department of Climate Change and Energy Efficiency

GEO

Group on Earth Observations

DDT

Dichlorodiphenyltrichloroethane

UN

United Nations.

\section{Declarations}

Ethics approval and consent to participate:

Not applicable

\section{Consent for publication:}

Not applicable

\section{Availability of data and material:}

Data available through the following link: https://osf.io/pxnc8/?

view_only=eb1a49fc5dd2416e8403a46d0ae827e2

\section{Competing interests:}

The Gaia hypothesis first proposed by James Lovelock in 1969 stated "all living things on earth function as one super organism that changes its environment to create conditions that best meet its needs". In addition, hypothesis further justifies, that all living things (super organism) poses the ability to self-regulate the system by successfully adapting to the changes or by overcoming the changes by its natural resilience. This cooperative not competitive process ascertains the continuity of life on this planet through evolution. However, in this Anthropocene era man-made environmental problems severely affect this natural self-regulating and co-operative phenomenon. Man-made environmental problems are the human caused changes in the environment that alters the surrounding and makes it unfavourable for life existence. According to (1), in the early days environmental issues gained public attention due to either their impacts on communities or prediction of such problems by scientists and others on likely effects of certain issues before these problems capture the wide recognition. According to (1), early environmental issues such as fish kill in contaminated surface waters, smog hazes over many American cities, the effects of DDT and other pesticides on wildlife, effects of acid rain on ecosystems, effects of lead on infants and children, effects of tributyl tin on marine environment were considered as environmental problems and increased public concern on these issues caused US EPA to pass few laws in order to protect the environment and people such as clean air act, clean water act and safe drinking water act. As a result, problems such as lead poisoning, air and water pollution 
were successfully mitigated in the period between 1978 and 1995. In addition, international treaties such as Montreal protocol (1987) which led to take measures to protect stratospheric ozone layer by banning CFC and related products globally and enabled us to recover from the impacts of UV radiation. It is further stated in the (1), that environmental systems are complex and interconnected.

Interestingly, man-made environmental issues are on a hike. During 1960s people aware on pesticide pollution as they read on Rachel Carson's Silent Spring but none had ever heard the term plastic pollution and e-waste issue. Even global climate change, ocean acidification, ozone depletion and acid rain are not so prominent at that time. Similarly, Aldo Leopold's "The Land Ethic" referred his work in forestry and wildlife, and "Sand country Almanac" was a literature on environmental movement. In addition, "State of the world" series by world watch institute discussed about trends in sustainable development and issues such as population, energy, agriculture, health, and trade policy. In 1970's the book named "Soft energy paths" by Amory B. Lovins discussed about renewable energy sources such as solar, wind, geothermal, biofuel, etc. A book named "Natural capitalism" authored by Paul Hawken, Amory B. Lovins, et al. noted issues related to natural capitalism, brings out ecologically smart choices for business on natural resources. "The Ecology of commerce" authored by Paul Hawken proposes a business culture in which natural world is allowed to flourish while the planet's needs are considered. "Steady state economics" (first published in 1977) is a widely accepted book in economics of sustainability authored by Herman Daly. The book "Population bomb" by Paul R. Ehrlich (1968) on population explosion predicted the possibility of mast starvation in the period between 1970 and 1980 and also called immediate action to this problem, "Our stolen future" authored by Theo Colborn advocated the impact of chemical pollution on human health as well as on the environment and it evidenced that birth defects, sexual abnormalities and reproductive failures occur due to the intense chemical usage, and the book "Scarcity and growth" by Harold J. Barnett and Chandler Morse expressed that the resource depletion does not affect the economic growth. I personally felt the need of more up-to-date knowledge on present status of the world environmental crisis, the same also mentioned in the GEO 6 report (Global Environmental Outlook of UNEP). Therefore, I also published several books on each environmental issue; books are available on amazon.com (or www.envo.yolasite.com). The games such as 'Enviropoly' and 'Green master's playing cards are designed not only as awareness air but also as a teaching tool for environmental education. In addition, I also have investigated the interconnected nature of man-made environmental problems. It is quite obvious that man-made environmental problems are interconnected as causes and effects. For instance, intensive farming causes agrochemicals, agrochemicals cause eutrophication. Similarly, greenhouse gas air pollution causes man-made global warming. I would like to examine the interconnected nature of the man-made environmental problems. The research can be designed as literature survey in order to demonstrate the existence of each links or the work that can be extended using a research on any identified man-made environmental problem. However, based on my six years of work experience as an environmental officer at Environmental Impact Assessment unit, Central Environmental Authority, Sri Lanka, I have come across several site inspections such as sanitary landfills, industrial sewage treatment, Air pollution control, eutrophication, deforestation and agroforestry, etc. (please see my resume). My current research interest falls on remediation and restoration of degraded environmental systems, as my pilot study on interconnected nature of environmental crisis may lead to the identification of keystone manmade environmental problems for the first time in the world. I have conducted research works in most important environmental issues in Sri Lanka such as impact of use of inorganic fertilizer for tobacco 
cultivation on groundwater nitrate problem in Jaffna peninsula and study on distribution and abundance of beach trash in Colombo district, as Sri Lanka is ranked in the $5^{\text {th }}$ place among world's most ocean trash producing countries.

Thus, my interest in man-made environmental problems is not just a greed for a Ph.D. title but my life itself. However, I have successfully completed my Ph.D. on the same. I'm living with this broad inspiring mission, and participated in several environmental awareness programmes such as awareness march and awareness beach cleanups on Ocean pollution on world Ocean day ( $8^{\text {th }}$ of June) and programmes on world biodiversity day $\left(22^{\text {nd }}\right.$ of May) etc. I swear if this paper selected for publication, it will ignite the spark throughout the world through this new discovery of keystone man-made environmental problems.

\section{Funding:}

Not Applicable

\section{Authors' contributions}

Sivaramanan S: This paper is the outcome of the doctoral research. The data collection, literature writing, documentation for results, construction of concept map, analysis, finding key links and defining keystone environmental problems, drafting discussion and conclusion done by this author. This interconnected environmental problem was initiated with the development of a board game 'Enviropoly' (2017) then author converted the concept of his own game into a study with the support of the supervisor.

Kotagama SW: Professor guided and supervised the study. He played a major role as time to time discussed with the researcher (Sivaramanan S) and suggested ways for improvements, professor also proof read and ameliorated the entire thesis document at the end of the study. Many grammatical and theoretical errors were corrected by him before the acceptance. All authors have read and approved the manuscript, and ensured that this is the case.

\section{Acknowledgements}

Authors thank staffs of Central Environmental Authority of Sri Lanka for supporting the study.

\section{References}

1. National Research Council; Division on Earth and Life Studies; Commission on Geosciences, Environment and Resources; Committee on Research Opportunities and Priorities for EPA. Environmental challenges. In Building a Foundation for Sound Environmental Decisions.: National Academies Press; 1997.

2. U.S.EPA. Strategic Plan for the Office of Research and Development. Final Report. ; 1996.

3. NRC. Aerosol Radiative Forcing and Climate Change. Washington, D.C.: National Research Council; 1996.

4. The Conversation. ; 2013 Accessed 20186 13. Available from: http://theconversation.com/masking-andunmasking-of-global-warming-by-aerosols-19990. 
5. Wahl DC. Designing Regenerative Cultures invites us to co-create thriving communities. In Wahl DC. Designing Regenerative Cultures. UK: Triarchy Press; 2016.

6. Christensen CM. The Innovator's Dilemma: When New Technologies Cause Great Firms to Fail Boston, MA: Harvard Business School Press; 1997.

7. Wahl D. Creating Sustainability? Join the Re-Generation! The Ecologist. 2016 Apr 25.

8. USEPA. Office of Policy Analysis and Office of Policy. Plannibng and Evaluation. Unfinished buisness: A comparative assessments of environmental problems. Overview report and Appendices I-IV. Wachington :, 1987.

9. Vicky NB, William CC, Bhavik B, Mark KD, Jennifer MA, Chris NP, et al. International comparisopns of environmental hazards. In Jeanne KX, Roger KE. Global Environmental Risk. London: United Nations University Press and Earthscan Publications Ltd; 2001. p. 55-147.

10. Stern PC, Harvy V, Fineberg. Understanding risk: Informing decisions in a democratic society. Washinton. 1996.

11. USNRC. Science and judgement in risk assessment. Washinton. 1994.

12. Hohenemser C, Roger KE, Robert KW. "Casual structure." In Robert KW, Hohenemser C, Jeanne KX. Perilous progress: Managing the hazards of technology. Boulder, Colorado: Westview Press; 1985. p. 4366.

13. UNDP. sustainabl edevelopment goals.; 2018. Available from: http://www.undp.org/content/undp/en/home/sustainable-development-goals.html.

14. National Research Council; Division on Earth and Life Studies; Commission on Geosciences, Environment and Resources; Committee on Research Opportunities and Priorities for EPA. Improving Our Understanding of Environmental Issues. In Building A Foundation for Sound Environmental Decisions.: National Academies Press; 1997. p. 13-36.

15. "eanet.asia".; n.d. Accessed 20187 11. Available from: http://www.eanet.asia/product/e_learning/page1_2.html.

16. Mandal FB. "http://ezinearticles.com". ; 2010 Accessed 201812 27. Available from: http://ezinearticles.com/? Interconnected-Environmental-Problems\&id=5337231.

17. Adu P. Understanding Qualitative Content Analysis.; 2017 Accessed 202010 23. Available from: https://www.slideshare.net/kontorphilip/qualitative-content-analysis-for-systematic-reviews.

18. Sivaramanan S, Kotagama S. Examine the interconnected nature of the man-made environmental problems in a global prospective. In 3rd World Summit on Climate Change and Global Warming (EuroSciCon Conference on Climate change); 2019; Courtyard by Marriott Prague Airport , Czech Republic: Euroscicon Ltd.

19. Olivier JGJ, Janssens-Maenhout, Muntean , Jeroen PAHW. Trends in global CO2 emissions: 2013 Report. JRC Technical Note. ; 2013.

20. Nixon A, Curran. publications.gc.ca. ; 1998 Accessed 201910 15. Available from: http://publications.gc.ca/Collection-R/LoPBdP/CIR/7937-e.htm\#ISSUE.

21. Owens B. "thenarwhal.ca". ; 2019. Available from: https://thenarwhal.ca/acid-rain-not-over-yet-tinyshrimp/. 
22. Tiseo I. statista.com. ; 2020 Accessed 202010 14. Available from: https://www.statista.com/statistics/501303/volume-of-sulfur-dioxide-emissions-us/.

23. Chris CP. Tropical Rain Forests New York: Rutledge; 1992.

24. Parry , Canziani , Palutikof , Linden PJvd, Hanson. Impacts, Adaptation and Vulnerability. Contribution of Working Group II to the Fourth Assessment Report of the Intergovernmental Panel on Climate Change Cambridge, UK: Campridge university press; 2007.

25. Miteva D, Loucks C, Pattanayak S. Social and Environmental Impacts of Forest Management Certification in Indonesia. PLoS One. 2015 Jul 01; 10(07).

26. Grosberg RK, Vermeij GJ, Wainwright PC. Biodiversity in water and on land. Current Biology. 2012 Nov 6; 22(21): p. R900- R903.

27. Bai Z, Dent, Wu , Jong Rd. Land Degradation and Ecosystem Services. In Lal , Lorenz K, Hüttl RF, Schneider BU, Braun Jv. Ecosystem Services and Carbon Sequestration in the Biosphere.: Springer Science \& Business Media Dordrecht; 2013.

28. Sustainable Europe Research Institute (SERI), Austria and GLOBAL 2000 (Friends of the Earth Austria). ; 2009 Accessed 201602 13. Available from: https://www.foe.co.uk/sites/default/files/downloads/overconsumption.pdf.

29. "Unsustainable fishing". ; 2015 Accessed 201503 30. Available from: http://wwf.panda.org/about_our_earth/blue_planet/problems/problems_fishing/.

30. " Destructive fishing practices". ; 2015 Accessed 201503 30. Available from: http://wwf.panda.org/about_our_earth/blue_planet/problems/problems_fishing/destructive_fishing/.

31. Waldman. https://www.scientificamerican.com. ; 2018 Accessed 201911 3. Available from: https://www.scientificamerican.com/article/human-pressures-have-shrunk-wildlife-populations-by-60percent/.

32. Finding Solutions Together. Proposal - The Energy Crisis and Climate Change. In Global Economic Symposium; 2016.

33. Rinkesh. "what is the Energy Crisis? Conserve-energy-future.com". ; 2016 Accessed 201602 . Available from: http://www.conserve-energy-future.com/causes-and-solutions-to-the-global-energy-crisis.php.

34. International Energy Agency (IEA) WEO-2016 Special Report Energy and Air Pollution. Paris, France:; 2016.

35. Perera. Pollution from Fossil-Fuel Combustion is the Leading Environmental Threat to Global Pediatric Health and Equity: Solutions Exist. Int J Environ Res Public Health. 2018 Jan; 15(1): p. 16.

36. OECD Green growth studies: Energy. ; 2011.

37. Bridgeman. sentientmedia.org. ; 2020 Accessed 202010 30. Available from: https://sentientmedia.org/intensive-agriculture/.

38. Feuerbacher , Luckmann , Boysen , Zikeli , Grethe. Is Bhutan destined for $100 \%$ organic? Assessing the economy-wide effects of a large-scale conversion policy. Plos One. 2018 Jun 13; 13(6).

39. The state of the world's land and water resources for food and agriculture (SOLAW): managing systems at risk. Rome and Earthscan, London:; 2011. 
40. Water for Sustainable Food and Agriculture: A report produced for the G20 Presidency of Germany. Rome:; 2017.

41. Water at a Glance: the relationship between water, agriculture, food security and poverty. Rome:; n.d.

42. Agriculture is the direct driver for worldwide deforestation. Bangkok climate change negotiations. ; 2012.

43. "www.worldwildlife.org". ; n.d. Accessed 202010 30. Available from: https://www.worldwildlife.org/threats/water-scarcity.

44. Epstein P, Ford T, Puccia C, Possas CDA. Marine Ecosystem Health. Implications for Public Health. New York Academy of Sciences. 1994; 740: p. 13-23.

45. Robbins RH. The Political Economy of Twinkies: An Inquiry into the Real Cost of Things. ; 2000.

46. Pimentel D, Cooperstein S, Randell H, Filiberto D, Sorrentino S, Kaye B, et al. Ecology of Increasing Diseases: Population Growth and Environmental Degradation. Hum Ecol. 2007; 35: p. 653-668.

47. "UN.org". ; 2018 Accessed 202010 30. Available from: https://www.un.org/development/desa/en/news/population/2018-revision-of-world-urbanizationprospects.html.

48. Climate Action Summit. ; 2019.

49. "energy.gov". ; 2013 Accessed 201911 11. Available from: https://www.energy.gov/oe/articles/10-yearsafter-2003-northeast-blackout.

50. "darksky.org". ; 2016 Accessed 201911 11. Available from: https://www.darksky.org/80-of-worldpopulation-lives-under-skyglow-new-study-finds/.

51. Carlson. Light Pollution. Arizona; n.d. Accessed 201911 11. Available from: https://www.darksky.org/wpcontent/uploads/2014/09/Blackout_Todd_CarlsonTowards_Toronto_Goodwood_Ontario.jpg.

52. "123HelpMe.com". ; 2016 Accessed 2016. Available from: http://www.123helpme.com/view.asp? id $=19868$.

53. www.panda.org. ; 2016 Accessed 2016. Available from: http://wwf.panda.org/about_our_earth/biodiversity/biodiversity/.

54. Harvey F. www.theguardian.com/. ; 2019 Accessed 201911 5. Available from: https://www.theguardian.com/news/2019/jan/28/can-we-ditch-intensive-farming-and-still-feed-theworld.

55. "How to Food the world in 2050". ; n.d. Accessed 201911 5. Available from: http://www.fao.org/fileadmin/templates/wsfs/docs/expert_paper/How_to_Feed_the_World_in_2050.pdf.

56. www.un.org. ; 2018 Accessed 20195 11. Available from: https://www.un.org/development/desa/en/news/population/2018-revision-of-world-urbanizationprospects.html.

57. www.theguardian.com. ; 2018 Accessed 201911 5. Available from: https://www.theguardian.com/environment/2018/mar/19/water-shortages-could-affect-5bn-people-by2050-un-report-warns. 
58. Malik, Yasar, Tabinda , Abubakar. Water-Borne Diseases, Cost of Illness and Willingness to Pay for Diseases Interventions in Rural Communities of Developing Countries. Iran J Public Health. 2012; 41(6): p. 39-49.

59. www.unenvironment.org. ; 2017 Accessed 201911 5. Available from: https://www.unenvironment.org/news-and-stories/press-release/resource-use-expected-double-2050better-natural-resource-use.

60. www.un.org. ; 2018. Available from: https://www.un.org/development/desa/en/news/forest/haltingdeforestation-for-sdgs.html.

61. "about.bnef.com".; 2018 Accessed 201911 5. Available from: https://about.bnef.com/blog/globalelectricity-demand-increase-57-2050/.

62. Wahl DC. Designing Regenerative Cultures invites us to co-create thriving communities. In Wahl DC. Designing Regenerative Cultures. UK: Triarchy Press; 2016.

63. Sarkar S, Pfeifer J. The Philosophy of Science: A-M: Taylor \& Francis; 2006.

64. "fao.org". Rome; 2006 Accessed 20191015 [Rome]. Available from: http://www.fao.org/newsroom/en/news/2006/1000385/index.html.

65. Annan. 'water-related diseases responsible for 80 per cent of all illnesses, deaths in developing world', says secretary-general in environment day message.; 2003 Accessed 201910 21. Available from: https://www.un.org/press/en/2003/sgsm8707.doc.htm.

66. Lang SS. Cronell Chronicle. ; 2007 Accessed 201910 23. Available from: http://news.cornell.edu/stories/2007/08/pollution-causes-40-percent-deaths-worldwide-study-finds.

67. Status of the World's Soil Resources (SWSR)-technical summary. Rome, Italy:; 2015.

68. International Energy Agency (IEA) Weo-2016 Special Report Energy and Air Pollution. Paris, France:; 2016.

69. Helfrich LA, Neves RJ, Libey G, Newcomb T. Extension Specialists. Fisheries and Wildlife Sciences. n.d..

70. Pieterse, Murphy KJ. Aquatic Weeds: The Ecology; 1990.

71. Oghenerobor BA, Tomilola DO, Gladys 00. Heavy Metal Pollutants in Wastewater Effluents: Sources, Effects and Remediation. Advances in Bioscience and Bioengineering. 2014; 2(4): p. 37-43.

\section{Figures}




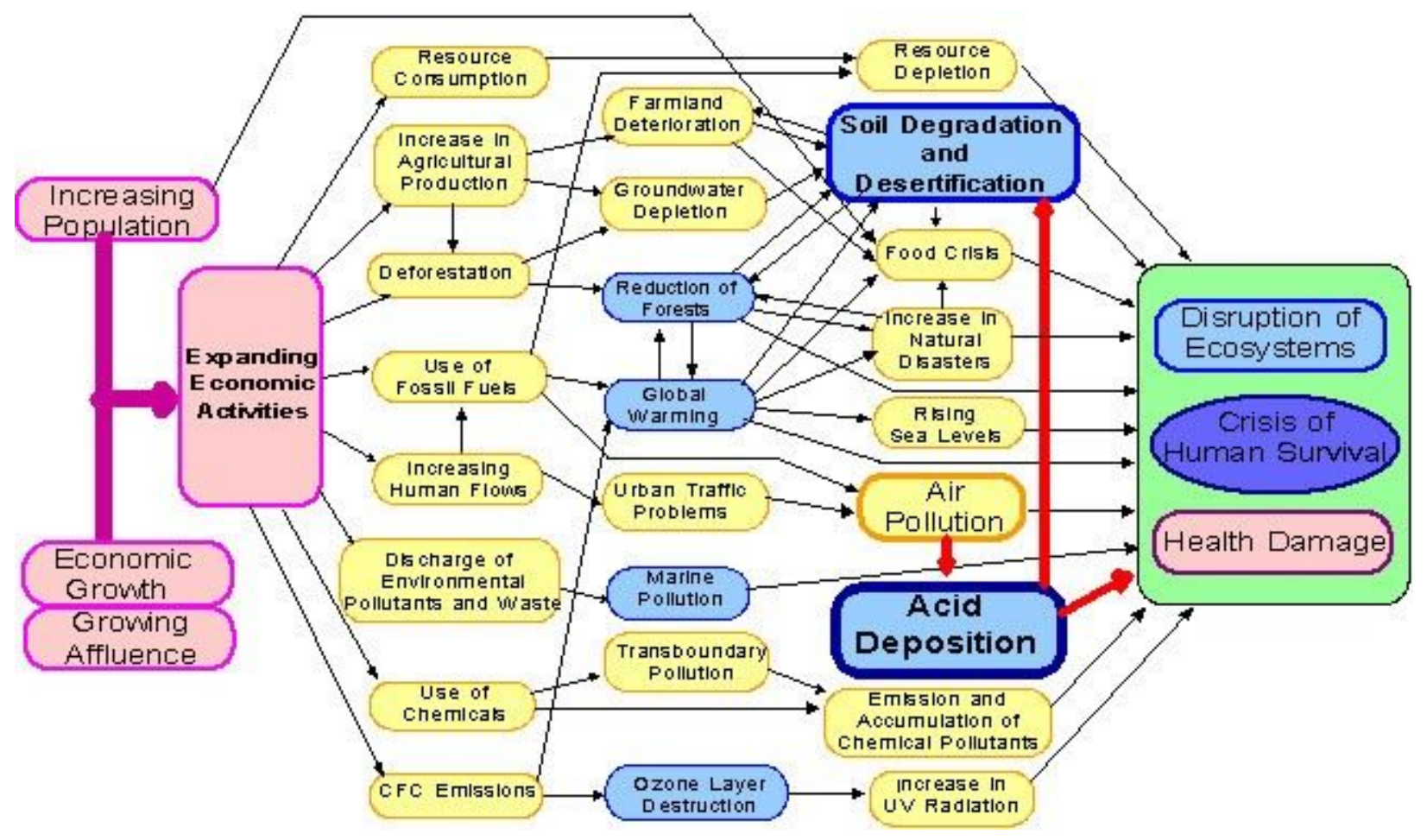

Figure 1

Global Environmental Issues as an Interconnected System

\section{Basic Understanding of Content Analysis}

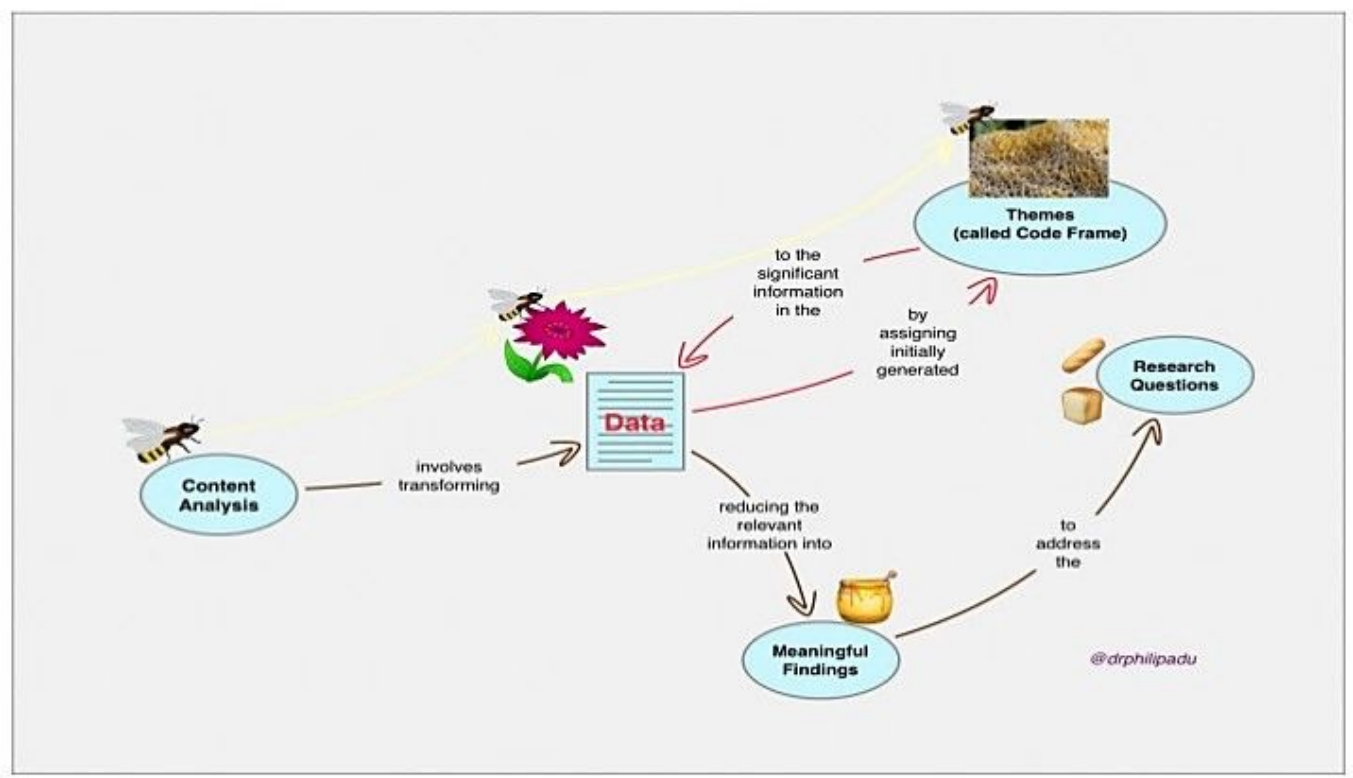

Source: Adu, P. (2017, February 24). Understanding Qualitative Content Analysis. Retrieved August 05, 2017, from https://www.slideshare.net/kontor philip/understanding-qualitative-content-analysis

\section{Figure 2}

Qualitative content analysis methodology 


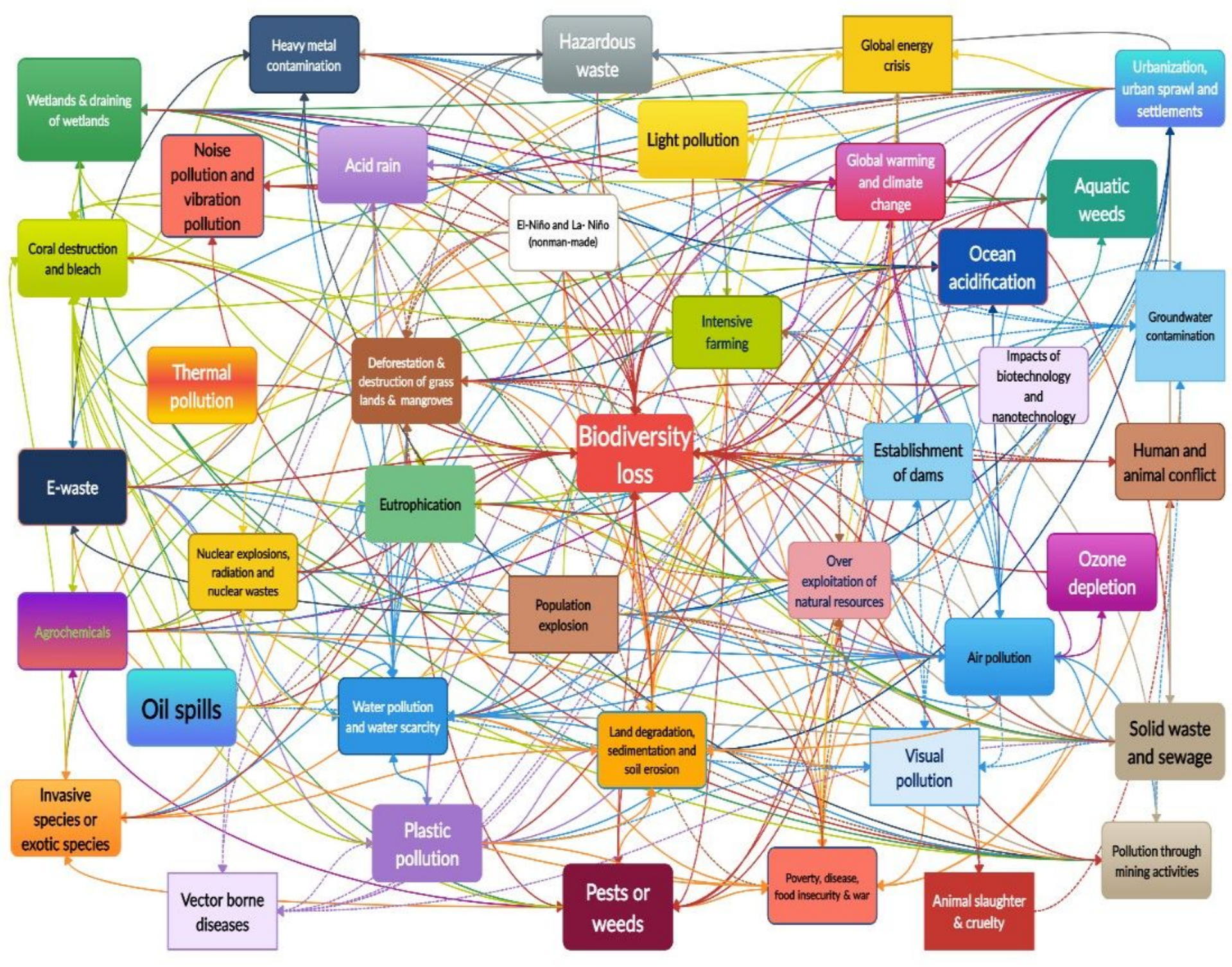

Figure 3

Concept map of interconnected man-made environmental problems based on cause-and-effect relationships 


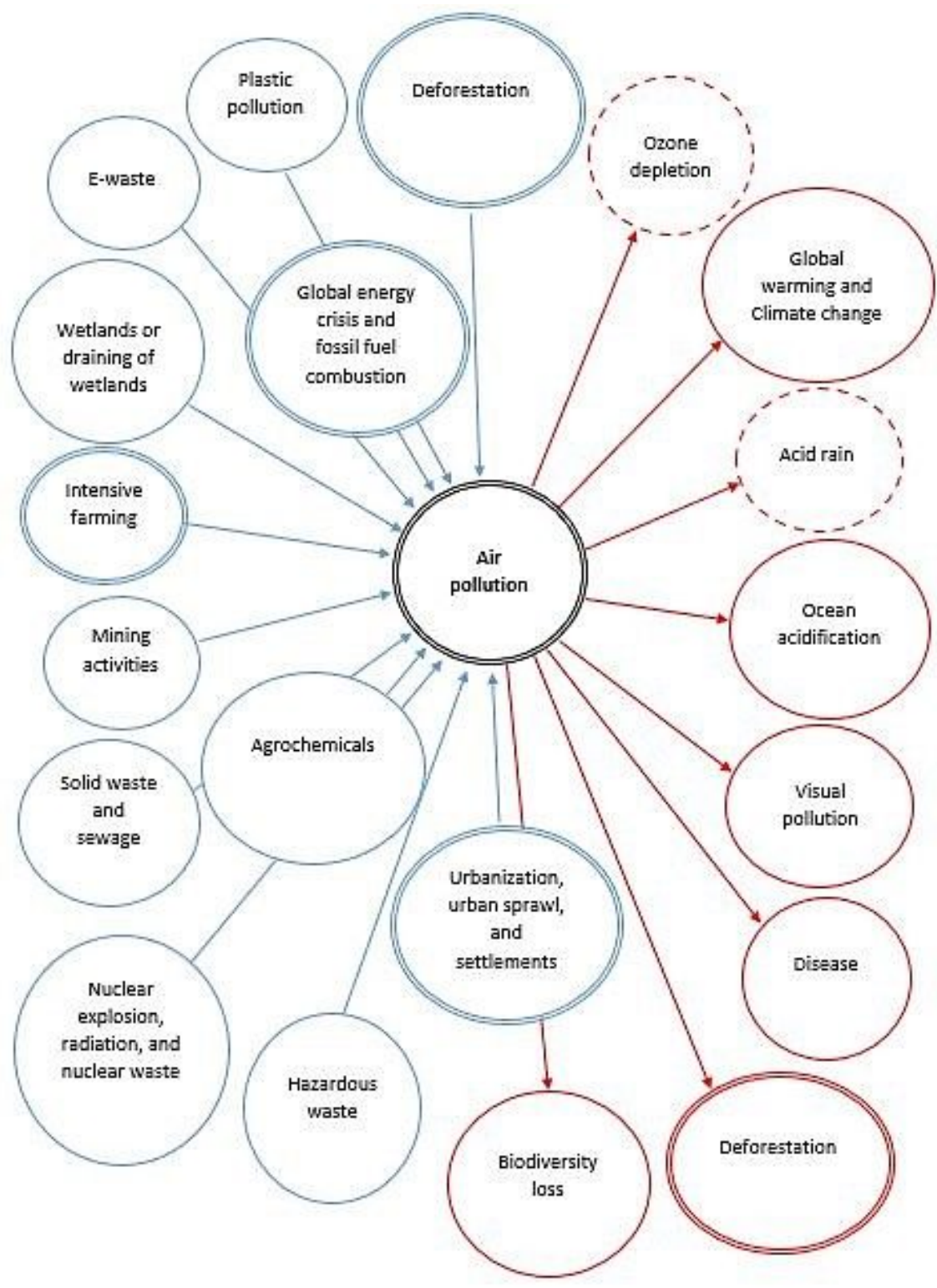

Figure 4

Air pollution as possible keystone environmental problem with the disappearance of ozone depletion and acid rain on its mitigation (hypothetical diagram) 


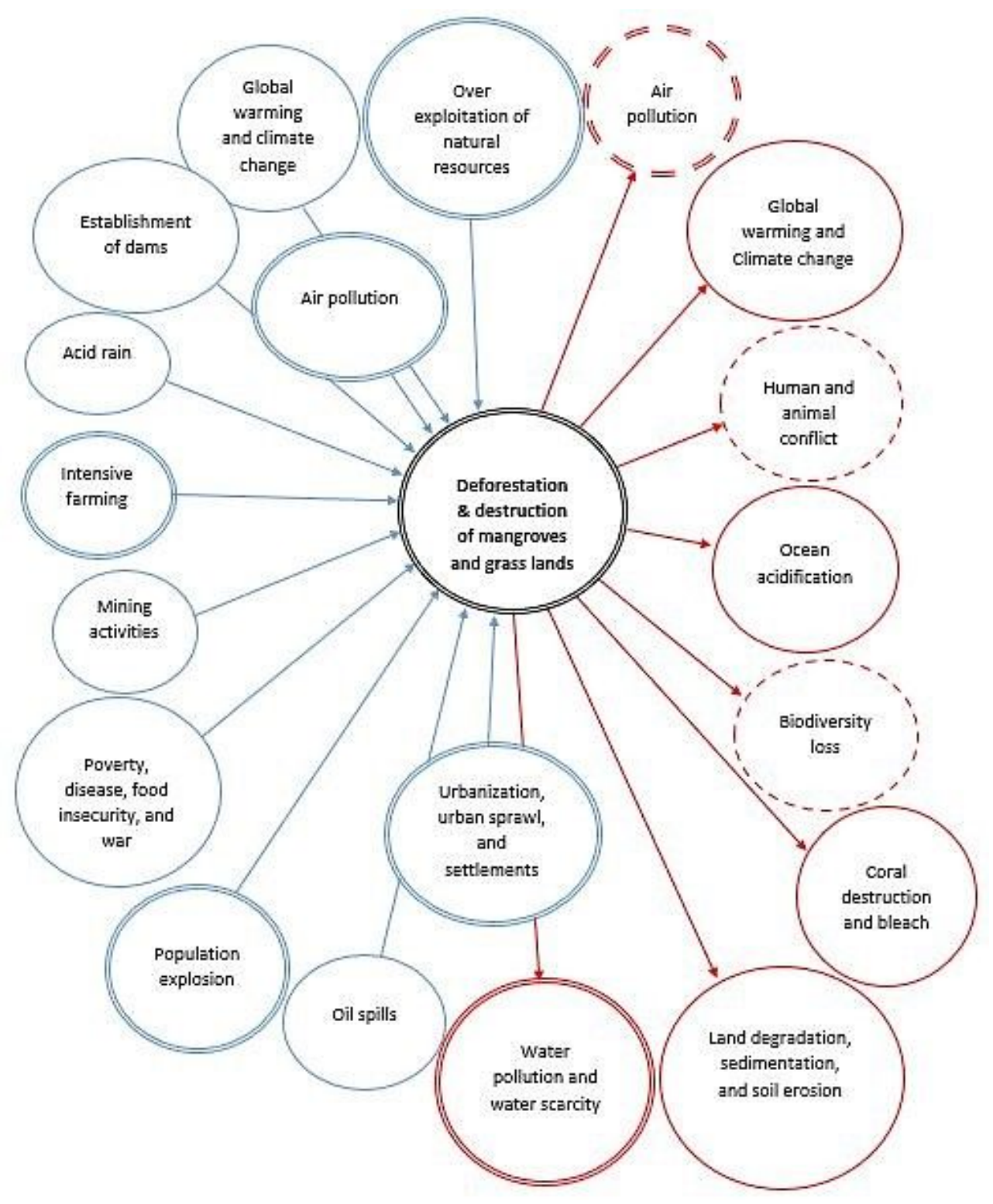

Figure 5

Deforestation as possible keystone environmental problem with the disappearance of desertification/ land degradation, air pollution, biodiversity loss and human\& animal conflict on its mitigation (hypothetical diagram) 


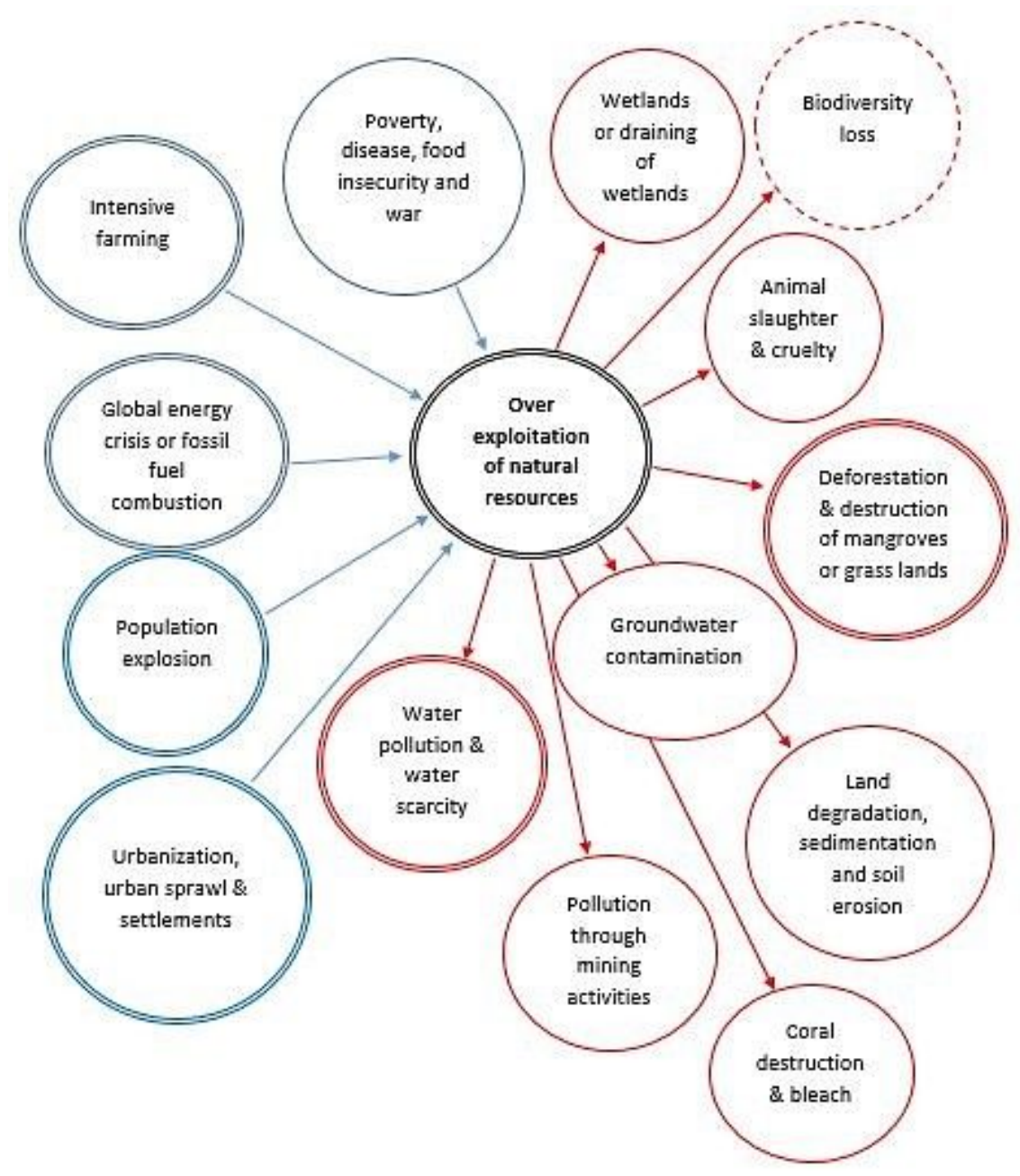

\section{Figure 6}

Overexploitation of natural resources as possible keystone environmental problem with the disappearance of biodiversity loss on its mitigation (hypothetical diagram) 


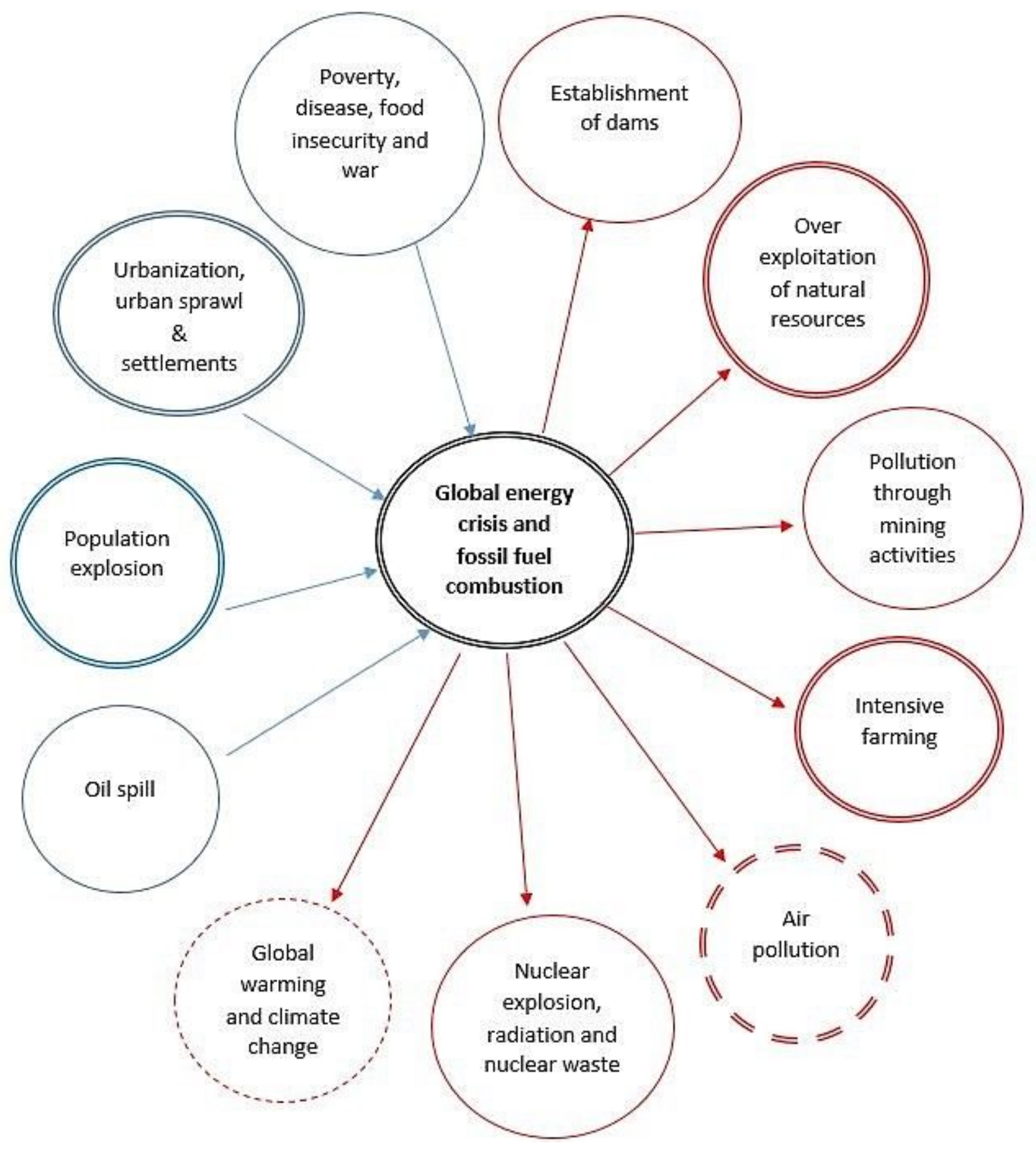

Figure 7

Global energy crisis as possible keystone environmental problem with the disappearance of air pollution on its mitigation (hypothetical diagram) 


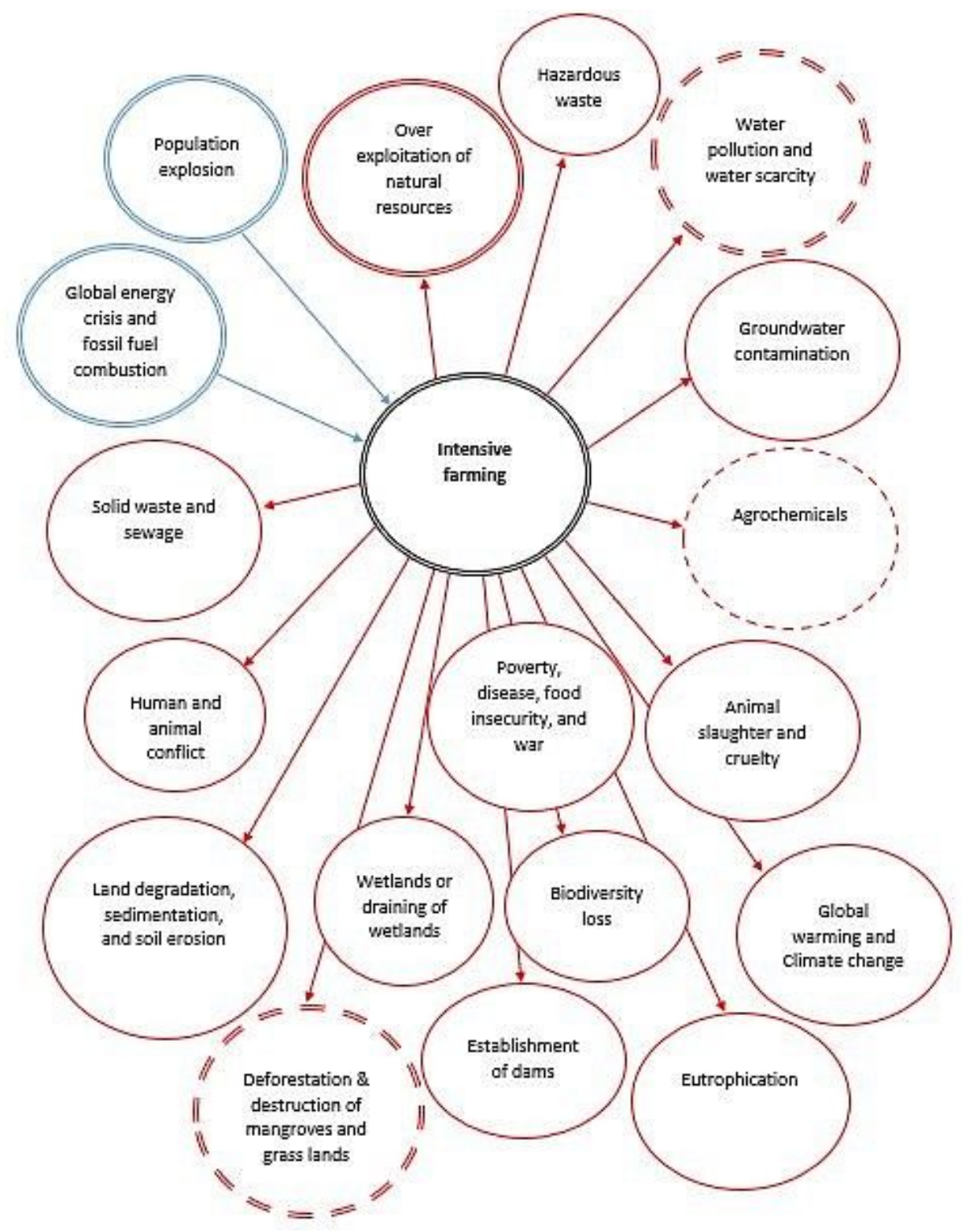

\section{Figure 8}

Intensive farming as possible keystone environmental problem with the disappearance of agrochemicals, water pollution-water scarcity, and deforestation on its mitigation (hypothetical diagram) 


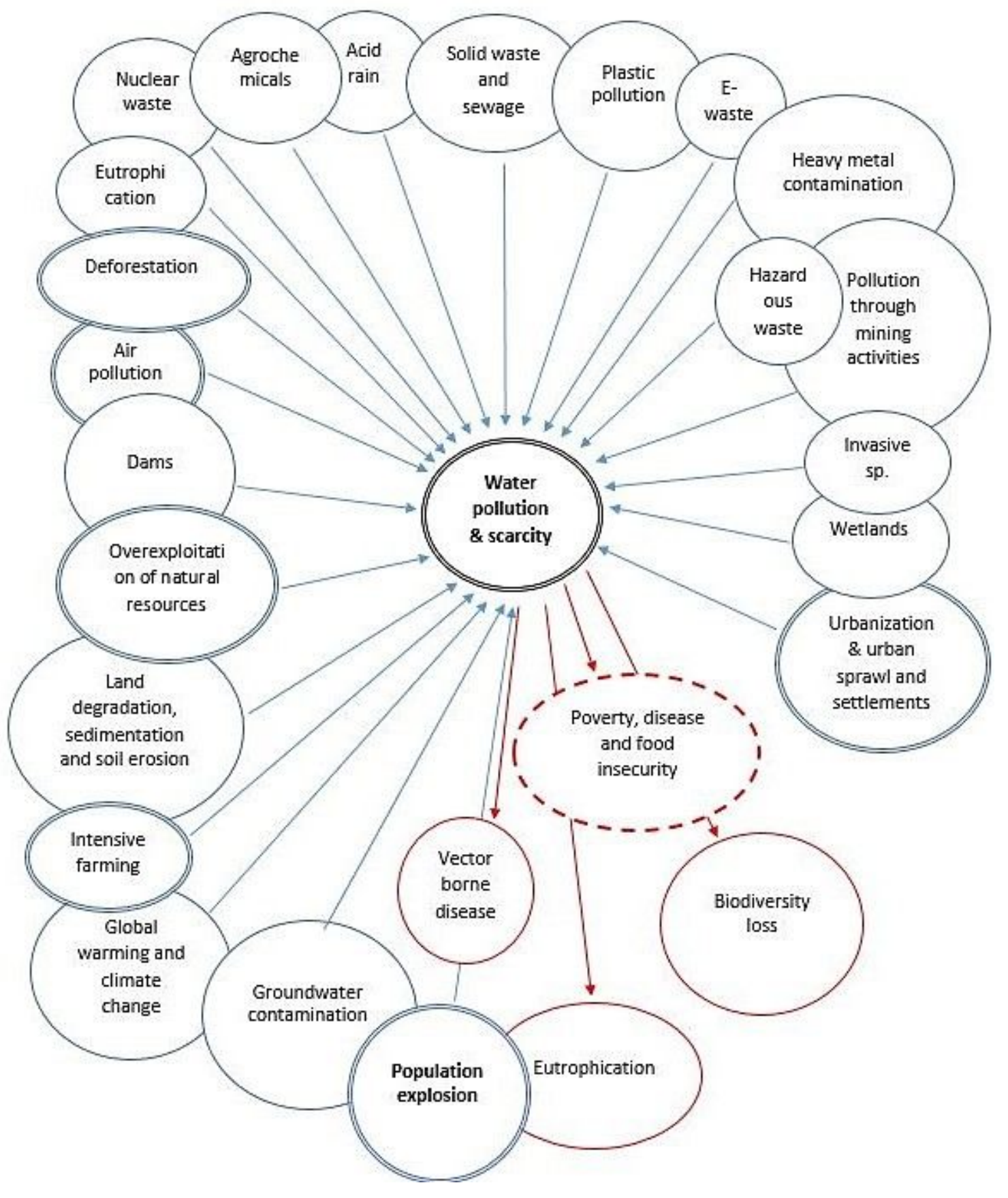

\section{Figure 9}

Water pollution-water scarcity as possible keystone environmental problem with the disappearance of disease and food insecurity on its mitigation (hypothetical diagram) 


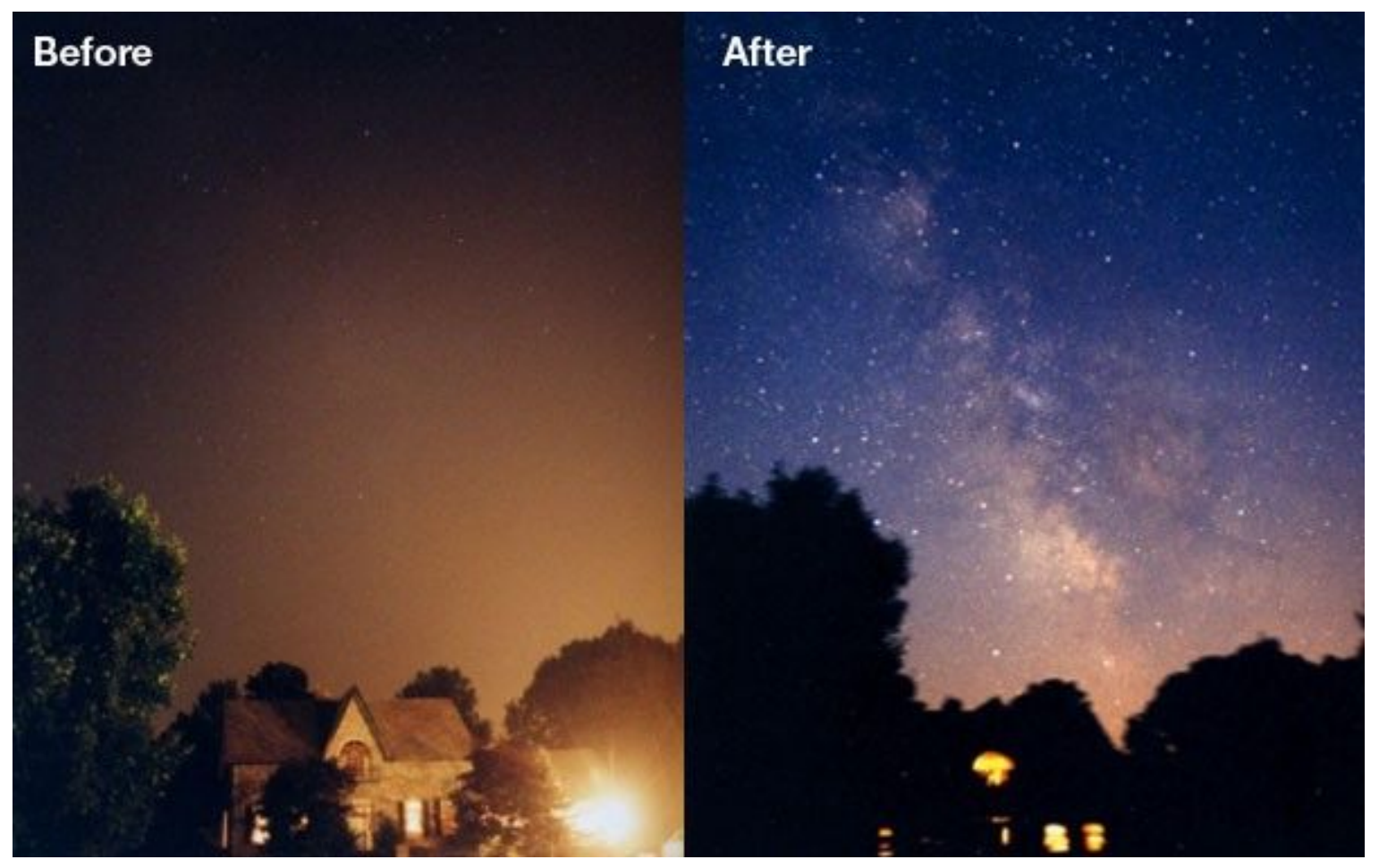

\section{Figure 10}

Before and during the 2003 Northeast blackout, a massive power outage that affected 55 million people. Photo by of Todd Carlson. 


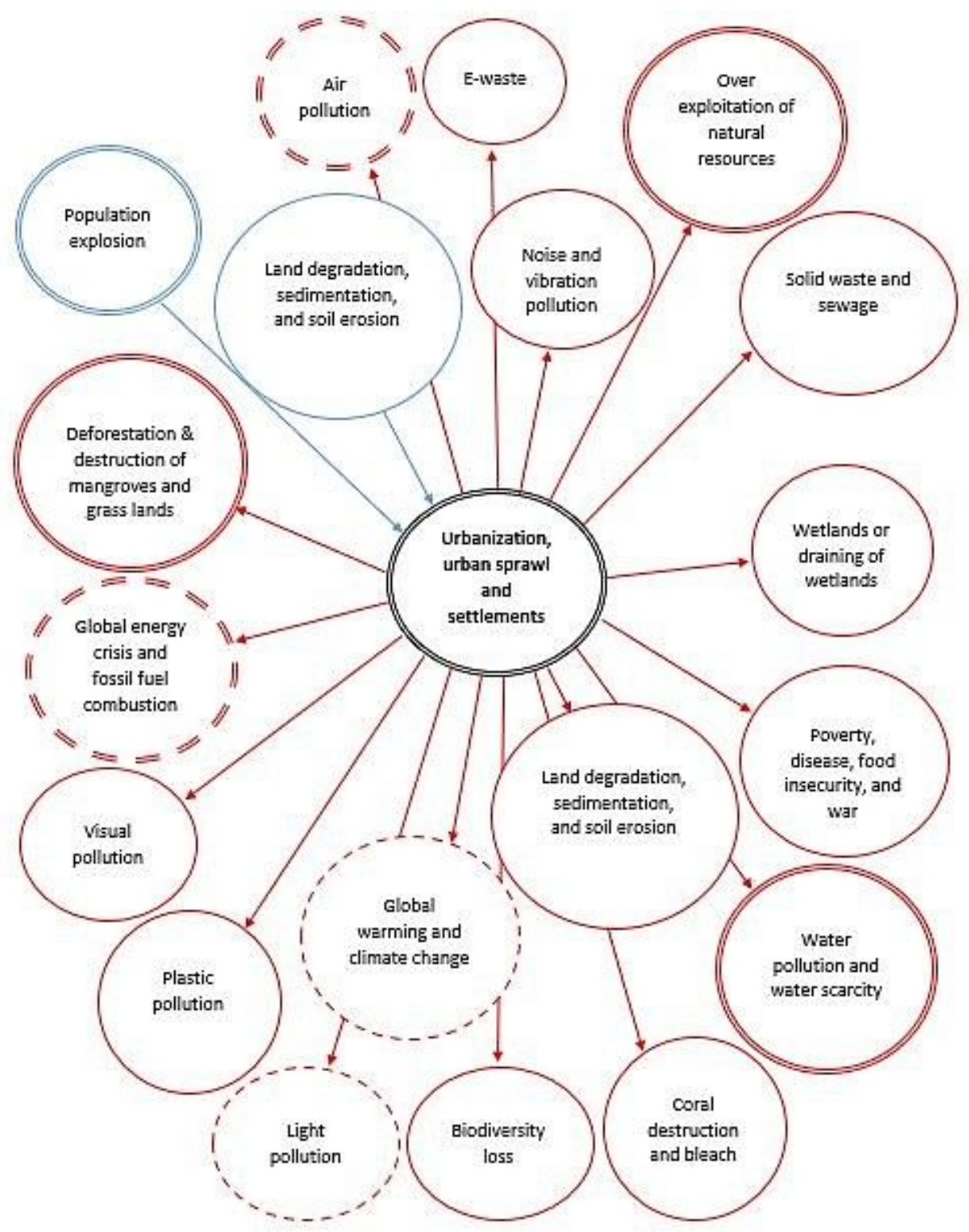

Figure 11

Urbanization-urban sprawl-settlements as possible keystone environmental problems with the disappearance of air pollution, global energy crisis, and light pollution on its mitigation (hypothetical diagram). 


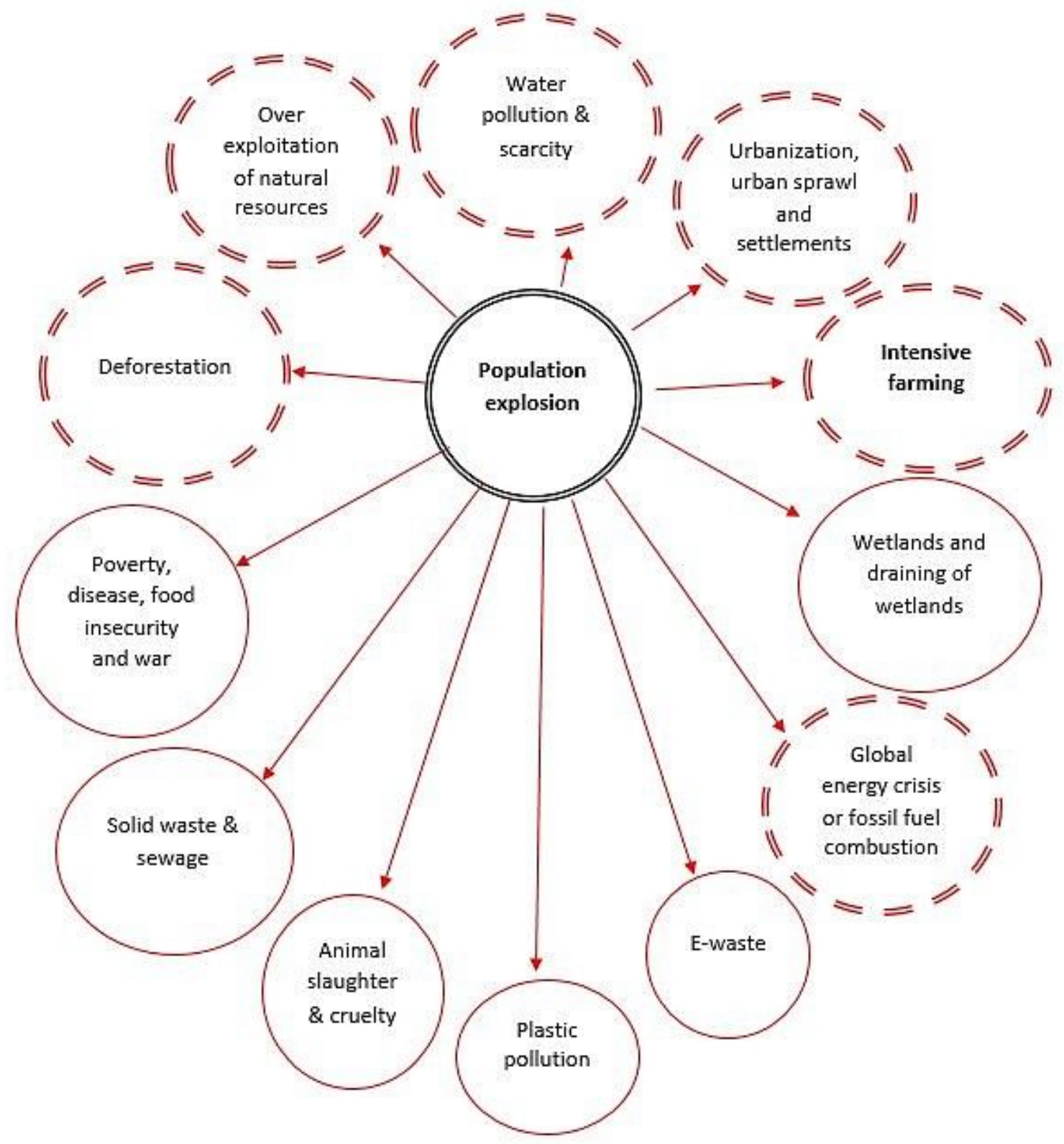

Figure 12

Population explosion as possible keystone environmental problem with the disappearance of intensive farming, deforestation, urbanization, water pollution-water scarcity, and overexploitation of natural resources on its mitigation (hypothetical diagram) 




Figure 13

Path of the possible keystone man-made environmental issues (hypothetical diagram) 

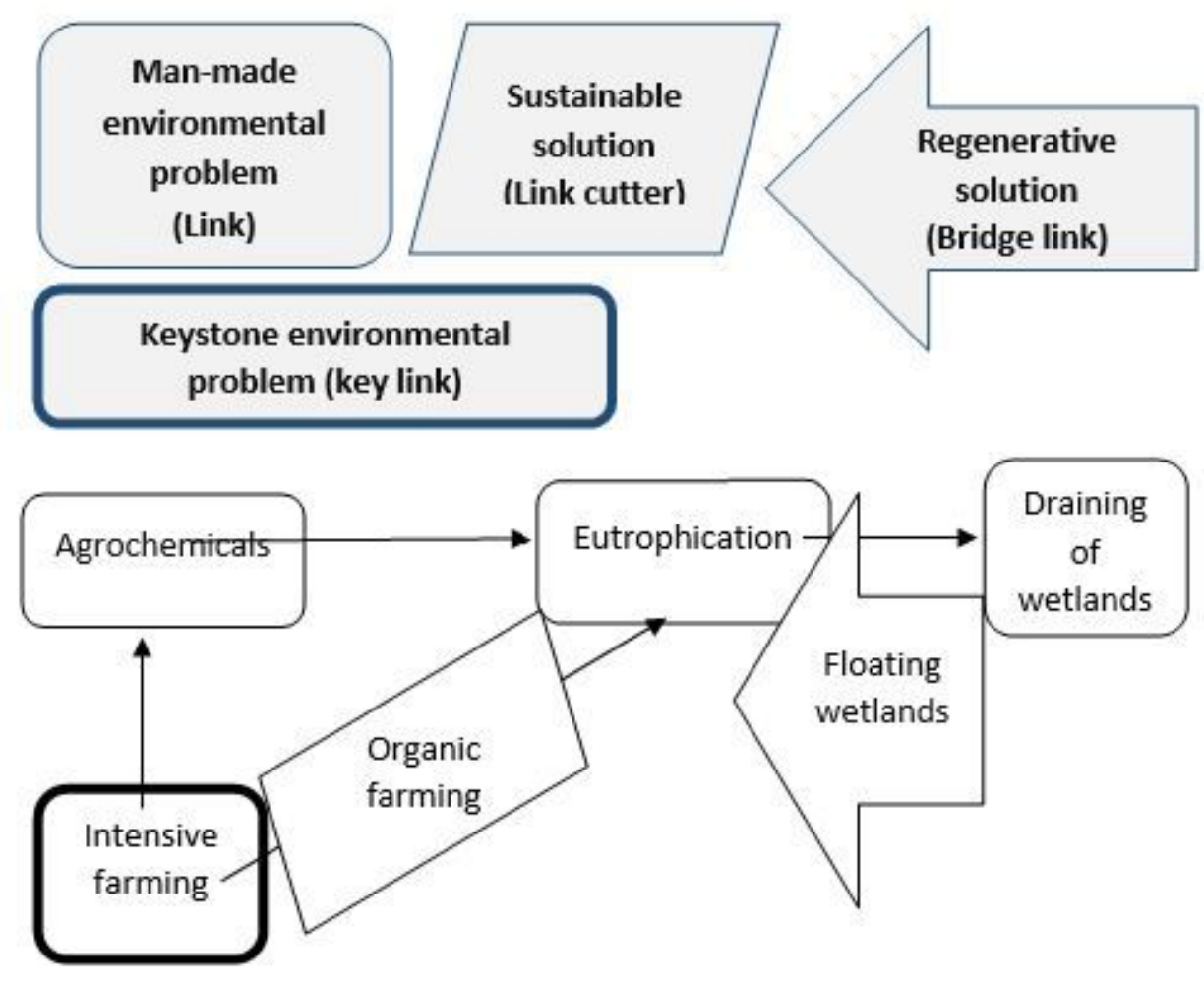

Figure 14

Sustainable and regenerative solutions to linked man-made environmental problems

\section{Supplementary Files}

This is a list of supplementary files associated with this preprint. Click to download.

- supplimentrymaterial.docx 